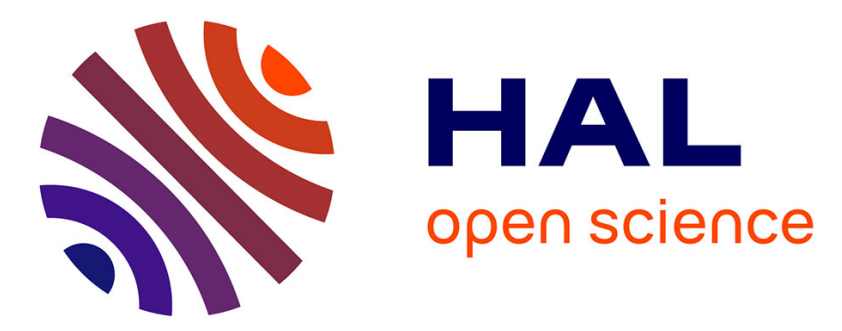

\title{
Mechanisms of margin inversion in the external Western Alps: Implications for crustal rheology
}

Nicolas Bellahsen, Laurent Jolivet, Olivier Lacombe, Mathieu Bellanger, Alexandre Boutoux, S. Garcia, Frédéric Mouthereau, Laetitia Le Pourhiet, Charles Gumiaux

\section{To cite this version:}

Nicolas Bellahsen, Laurent Jolivet, Olivier Lacombe, Mathieu Bellanger, Alexandre Boutoux, et al.. Mechanisms of margin inversion in the external Western Alps: Implications for crustal rheology. Tectonophysics, 2012, 560-561, pp.62-83. 10.1016/j.tecto.2012.06.022 . insu-00715925

\section{HAL Id: insu-00715925}

\section{https://hal-insu.archives-ouvertes.fr/insu-00715925}

Submitted on 24 Aug 2012

HAL is a multi-disciplinary open access archive for the deposit and dissemination of scientific research documents, whether they are published or not. The documents may come from teaching and research institutions in France or abroad, or from public or private research centers.
L'archive ouverte pluridisciplinaire HAL, est destinée au dépôt et à la diffusion de documents scientifiques de niveau recherche, publiés ou non, émanant des établissements d'enseignement et de recherche français ou étrangers, des laboratoires publics ou privés. 


\section{Mechanisms of margin inversion in the external Western Alps: implications for crustal rheology}

N. Bellahsen ${ }^{1}$, L. Jolivet ${ }^{2}$, O. Lacombe ${ }^{1}$, M. Bellanger ${ }^{2}$, A. Boutoux ${ }^{1}$, S. Garcia ${ }^{3}$, F. Mouthereau $^{1}$, L. LePourhiet ${ }^{1}$, C. Gumiaux ${ }^{2}$

\footnotetext{
${ }^{1}$ Univ. Pierre et Marie Curie, iSTeP UMR 7193 UPMC-CNRS, 4 place Jussieu, Case 129, T46-00, 2ème étage. 4 place Jussieu. 75252 Paris cedex 05

${ }^{2}$ Univ. Orléans, ISTO INSU-CNRS, Campus Géosciences, 1A rue de la Ferollerie, 45071 Orléans cedex 02

${ }^{3}$ Freie Universität Berlin - FR Geologie. Haus B - Malteserstrasse 74-100 - D-12249 Berlin
}

Corresponding author: Nicolas Bellahsen

Nicolas.bellahsen@upmc.fr

Université Pierre et Marie Curie

iSTeP UMR 7193 UPMC-CNRS

Case 129, T46-00, 2ème étage

4 place Jussieu

75252 Paris cedex 05

tel.: +33144277464 fax: +33144275085 


\begin{abstract}
The kinematics of the collisional crustal wedge in the external Western Alps is discussed in the light of new cross sections of the whole external zone at the latitude of the BelledonneGrandes Rousses-Oisans massifs (External Crystalline Massifs, ECM), as well as a detailed analysis of the deformation of their basement and cover. The cross sections were built from new field data and published geological maps, and were restored through time (OligoMiocene times) to unravel the successive stages of the Dauphinois margin contractional deformation. During Oligocene times, the Variscan basement was deformed essentially by greenschist facies Alpine distributed shear zones with no significant reactivation of the inherited Jurassic normal faults or the Variscan foliation. However, the inherited syn-rift basins localized the deformation characterized by a thick-skinned style and a cover disharmonically folded over basement shear zones, with no major décollement in between (shortening of $11.5 \mathrm{~km}, 20 \%$ ). Those early deformations progressively localized on the frontal crustal ramp and caused shortening in the folded belt (16.5 km of shortening, 23\%). A similar sequence of deformation has been inferred in other Alpine ECMs. This strongly suggests that the crust of Dauphinois proximal passive margin was thin enough, and its buoyancy low enough (as a result of the Liassic rifting), to experience significant tectonic burial during the Tertiary collision. As a consequence of a weakening by both the presence of inherited basins (and their weak syn-rift sediments) and the P,T conditions (greenschist facies), the crust was shortened and the structural style was thick-skinned.
\end{abstract}

Keywords: Collision, External Western Alps, Passive margin inversion, Shear zones

\title{
1. Introduction
}


Crustal shortening occurs on Earth in different convergent settings: in collisional orogens (with an oceanic suture, e.g. Alps, Himalayas, and Variscan orogens), in intracontinental orogens (e.g. Pyrenees), in continental cordillera (e.g. Andes, Rocky Mountains), or in more peculiar conditions (e.g. Taiwan). In these different settings, the main questions are: what are the respective contributions of crustal shortening and subduction during convergence and how does this evolve through time? Answering these questions may help constrain crustal rheology at the time of collision: indeed, a strong and dense crust will presumably tend to subduct (e.g. Burov and Yamato, 2008) while a light and weak crust will tend to shorten and thus to be exhumed earlier. Such behaviours evolve though time (and space) as both the plate kinematics and the initial tectonic/thermal/lithological crustal properties also vary in space (and time) during convergence.

To estimate crustal strength and rheological stratification of the lithosphere, one can make use of the earthquake distribution, the structural style and the amount of shortening (thin-vs thick-skinned tectonics; Mouthereau and Petit, 2003; Mouthereau and Lacombe, 2006) or alternatively estimate the equivalent elastic thickness to constrain the long-term strength of continents (Watts et al., 1995; Burov and Diament, 1995). Comparisons with parametric numerical studies (e.g. Burov and Yamato, 2008; Kaus et al., 2008; Faccenda et al., 2009; Yamato et al., 2009) may also help discuss the rheological stratification of the lithosphere. Thin-skinned tectonics is usually seen as witnessing a rather strong lithosphere when the basement (i.e. the main part of the upper crust) subducts below the orogenic prism, as it is too strong to undergo shortening; the cover being shortened over a décollement (Watts et al., 1995; Mouthereau and Petit, 2003; Mouthereau and Lacombe, 2006). Accordingly, in Taiwan and in the Andes, a strong lithosphere with large equivalent elastic thickness displays thinskinned tectonics, while a weaker lithosphere rather shows thick-skinned tectonics. 
Lithospheric strength, and more specifically crustal strength can also be approached through the study of deformation modes as well as of the eventual reactivation of inherited weaknesses. Mylonites witness a ductile behaviour, which, in the crust, implies a low strength (Ranalli, 1995) and probably deformations at middle to lower crustal levels. On the contrary, the reactivation of inherited faults probably indicates a rather strong (and brittle upper) crust as it suggests a high contrast between the internal strength of the main inherited faults compared to the overall crustal strength (Butler et al., 2006). Such a contrast would probably favour reactivation rather than the development of new faults (Sibson, 1995, and references therein). Evidence for fault reactivation, estimates of PT conditions, and inference of rock behaviour from microstructures and spatial distribution of seismicity may thus provide valuable constraints about the crustal strength. Beyond this, the amount and the style of shortening (thin vs. thick-skinned tectonics) are the main available geological data to discuss the crustal strength (and the rheological stratification of the lithosphere) during collision. Their quantification is possible in young (few tens of Ma) but inactive (or less active) orogens (e.g. Pyrenees and Alps). In such regions, the crust has usually been exhumed and eroded down to the basement-cover interface over large distance. If one can still observe the cover attached to the basement, this particular interface will provide the best available proxy for the quantification of crustal shortening, in the absence of any other unambiguous marker in the underlying basement (e.g. Van Baelen and Sintubin 2008).

The Alps (Fig. 1) are one of the most studied orogens and they provide the ideal location for such studies. They result from the closure of the Ligurian part of the Tethyan ocean (Lemoine et al., 1981). The Jurassic and Cretaceous oceanic and distal parts of the European continental margin were subducted beneath the conjugate Austro-Alpine margin until middle to late Eocene and the so-called collision started at Oligocene times with the shortening of the 
European proximal margin (known as Dauphinois or Helvetic domain, in France and Switzerland, respectively).

In this contribution, we provide a new complete balanced crustal cross-section of the whole external zone in the French Western Alps (Fig. 1), at the latitude of the South Belledonne/Grandes Rousses/Oisans External Crystalline Massifs (ECM), i.e. from the Valence basin to the West (WSW of Grenoble, Fig. 1) to the Penninic Frontal Thrust (PFT) to the East, as well as another shorter cross-section in the northern Grandes Rousses (Fig. 1 and 2). Along these transects, shortening-related structures (cleavages and shear zones mainly, both in the basement and the cover) are accurately described, and special emphasis is put on the absence of any major décollement between the cover and the basement. The cross-section further allows to discuss the role of inherited structures (pre-orogenic faults and rift-related basins), the spatial and temporal evolution of the structural style (thin- vs. thick-skinned), and the amounts of collisional shortening. The implications on crustal rheology at the time of collision are finally discussed.

\section{Geological setting and previous work}

The external western Alps are the result of the shortening of the proximal part of the European passive margin. During the Liassic to Dogger times, the crust was stretched and steep normal faults dissected the upper crust into several tilted blocks separated by halfgrabens with thick depocenters of marly sediments (Barféty et al., 1979; Lemoine et al., 1981; Lemoine et al., 1986; Tricart and Lemoine, 1986; de Graciansky et al., 1989). Since the end of Dogger times the oceanic basin opened and a thick post-rift sedimentary cover was deposited. In the Oisans massif (Fig. 1), this cover has been subsequently significantly eroded (Ford et al., 1996). 
Pre-Senonian folds recognized in the Devoluy (Fig. 1.; Ford et al., 1996 and references therein) supposedly mark the first Alpine deformation in the Western Alps, but the significance of these folds has been recently challenged by Michard et al. (2010) who reinterpreted them as huge gravity structures unrelated to any compressional event. Thus, Alpine deformation probably started with pre-Priabonian E-W thrusts caused by a N-S compression mainly described in the southern Oisans massif (Gidon, 1979; Ford, 1996; Sue et al., 1997; Dumont et al., 2008, 2011, in press).

In the eastern part of the Oisans massif (Fig. 1), now below the Penninic Frontal Thrust (PFT on Fig. 1), Priabonian limestones and flyschs (Dauphinois and Ultra-Dauphinois, eastern part of the proximal European margin) were deposited in the foreland basin. They were subsequently thrusted above the Mesozoic sequence northeast of the Oisans massif (Eocene, NE of Oisans on Fig. 1, Ultra-Dauphinois) or still unconformably overlie the basement in the Southeast (SE of Oisans on Fig. 1, Dauphinois).

In Oligocene times, the Dauphinois crust was tectonically buried below the internal units and started to thicken roughly at that time. From gravimetry (Bayer et al., 1996; Masson et al., 1999, 2002), wide angle and reflection data (Roure et al., 1990; Nicolas et al., 1990), and tomography (see Thouvenot et al., 2007 and references therein), the present-day Moho depth was estimated to 40 to $50 \mathrm{~km}$ below the Penninic Frontal Thrust, which supports (Oligocene and Miocene) thickening. Recently, Simon-Labric et al. (2009) obtained ages of about 31-34 Ma Alpine strike-slip shear zones in the basement (probably reactivating former Pyrenean faults, Simon-Labric et al., 2009; Dumont et al., 2011). In the sediments, a regional cleavage formed before $26 \mathrm{Ma}$ at temperatures around $300^{\circ} \mathrm{C}$ (Crouzet et al., 2001), which is confirmed by the presence of pyrophyllite and cookeite in the Liassic sediments $\left(280\right.$ to $350^{\circ} \mathrm{C}$ from west to east (Jullien and Goffé, 1993). Thus, those units might have been tectonically buried to depth of about $10 \mathrm{~km}$ assuming a $25^{\circ}-30^{\circ} / \mathrm{km}$ "normal" geotherm. Finally, apatite and 
zircon fission tracks suggest that the rocks crossed the $120^{\circ} \mathrm{C}$ and $240^{\circ} \mathrm{C}$ istotherms at about 7 and $20 \mathrm{Ma}$, respectively, with a pulse of rapid exhumation around $6 \mathrm{Ma}$ (see a recent synthesis in Vernon et al., 2008; van der Beek et al., 2010; and references therein).

In the external crystalline massifs, crustal thickening has been accommodated by "basement folds" (Ford, 1996, Gidon, 1999, Dumont et al., 2008; and references therein): they are characterized by a curved attitude of the Triassic layers (the part of the cover still attached to the basement). They have been mapped out in the field for several decades by Alpine geologists, but no kinematical explanation has ever been proposed. The outermost part of the external Alps consists of the Vercors and Chartreuse fold-and-thrust belts (Fig. 1). The cover thrusts root in a décollement located in the lower Liassic marly series (Deville et al., 1994; Philippe et al., 1998), which was activated at mid-Miocene times.

Thus, if the timing of the deformation of both cover and the basement is fairly well constrained, only few detailed cross-sections are available in the Alpine foreland to discuss the structural style, the amount of shortening, and the effect on the structural style of both the inherited Jurassic normal faults and their associated syn-rift basins. Available sections come from the Mont Blanc massif (Burkhard and Sommaruga, 1998), the Aar massif (Burkhard, 1988), and the Argentera massif (Ford et al., 2006; Lardeaux et al., 2006) for the whole external zone, and only partly in the Oisans massif (Dumont et al., 2008). In the Oisans, the crust is less deformed than in the Mont Blanc (Sinclair, 1997) and the basement-cover relationships are clearer. Thus, building a balanced cross-section at the scale of the whole external zone at this latitude and accurately constraining the evolution of basement and cover deformation along the section appear necessary to reliably discuss the structural style, the crustal rheology and the mechanisms of margin inversion.

\section{Results of analysis of collisional structures}


In the following, we present first two detailed cross-sections: one across the northern Grandes Rousses massif and focusing on "basement folding" (Fig. 2,3), and one (Fig 4, 5) in the southern Grandes Rousses and the northern Oisans massifs to illustrate field-based analysis of the cover and basement deformation (Fig. 4 to 13). Finally, a regional crosssection of the entire external Alps is presented. These results provide new insights into both the internal deformation in inverted inherited basins and the basement-cover coupling. All the sections were built approximately along an E-W trend in the ECM, as the main shortening direction is E-W (Malavieille, 1984) as witnessed by roughly E-W stretching lineation and NS cleavage (Fig. 2, 4, and 5).

\subsection{Detailed cross-sections and microstructures}

\subsubsection{The northern Grandes Rousses}

The northern Grandes Rousses cross-section (Fig. 2b) displays two main "basement antiforms", underlined by the Triassic layers (Fig. 2a). They are separated by a tight syncline of Liassic rocks, which is bounded to the west by a steep fault that offsets the Triassic layers and brings the Jurassic rocks directly over the basement. By comparison with other welldocumented faults (e.g. in Barfety et al., 1979; Lemoine et al., 1981), it is interpreted as an inherited Jurassic normal fault. Two Alpine west-verging thrusts deformed the metasediments.

In the eastern antiform, below the Triassic Fm., Stephanian (post-Variscan) rocks display a weakly marked steep schistosity (Fig. 2a,b, and 3a,b) where fine-grained micas formed between weakly deformed quartz, feldspars and chlorites. Within these N-S and sub-vertical schistosity planes, a sub-vertical stretching lineation parallel to that measured within the overlying Liassic marls indicates an E-W horizontal Alpine shortening associated to a nearly vertical stretching. 
In the basement, shear zones strike $020^{\circ} \mathrm{E}$ and dip $25^{\circ}$ to $50^{\circ} \mathrm{E}$ (Fig. 2a,b, and 3c,e). These shear zones bent the Alpine schistosity that also strikes $020^{\circ} \mathrm{E}$ and dips $40^{\circ}$ to $90^{\circ} \mathrm{E}$ (Fig. 2a,b) and reflect reverse, top-to-the-west basement shearing (Fig. 3c). Stretching lineations strike around E-W and are dip-slip (Fig. 2a). The shear zones contain a high amount of chlorite and white micas (Fig. 3d) indicating that they developed under greenschist facies conditions.

The first shear zones appear $\sim 300 \mathrm{~m}$ east of the syncline (Fig. 2a, b) and their spacing progressively decreases toward the syncline. In those shear zones, quartz clasts are mainly fractured but the overall mylonitic deformation mode is due to the high amount of white micas that grew contemporaneously with quartz deformation (Fig. 3d). Close to the syncline, grain size is minimum and shear zones and schistosity are nearly parallel (Fig. 3e,f). Such maximum shearing of the basement is observed where the Triassic is steeply dipping and locally overturned (Fig. 2b). In these zones, both angular and rounded quartz (with rather large micas and chlorite) are found in a fine-grained mica "matrix" that characterizes a phyllonite. Such rock might have deformed as a cataclasite first to break the quartz and the feldspar and subsequently evolved into a phyllosilicate-rich mylonite (phyllonite)(Fig. $\mathbf{3 f}$ ) as suggested by Wibberley (2005).

In the western antiform (Fig. 2a,b), other steep normal faults are associated with secondorder folds affecting the Triassic layers. On the section, a syncline can be observed in the hanging-wall of the normal fault, and just east of this syncline, the basement show westverging shear zones. Here again, steep Triassic layers well coincide with an intense shearing of the basement. Thus, the "folding" of the basement-cover interface is clearly spatially associated with shear zones, and therefore likely linked to non-coaxial shearing in the basement. 


\subsubsection{The Bourg d'Oisans basin (Southern Grandes Rousses)}

The Bourg d'Oisans basin is filled with Liassic and Dogger sedimentary rocks (Fig. 4 and 6) and consists of an inherited Jurassic half-graben (Barféty et al., 1979; Lemoine et al., 1981) inverted above Alpine basement thrusts/shear zones (Fig. 4 and 6). The cover is deformed by numerous folds, with steep axial planes striking roughly N-S and mainly dipping (steeply) toward the East. Such fold geometry supports overall westward non coaxial shearing of the Jurassic cover.

\section{The Ornon fault and the thickest part of the Bourg d'Oisans basin}

The Ornon fault (Fig. 6) is an inherited normal fault, bounding at the west the Bourg d'Oisans basin. Indeed, at Col d'Ornon, one can observe the famous outcrop where, in the Alps, Jurassic normal faults where originally described (Barfety et al. 1979; Lemoine et al. 1981). The Liassic rocks dip steeply toward the East (East of Ornon fault, Fig. 6) and display a cleavage oblique to bedding in competent marly layers (Fig. 7a), whereas it is instead parallel to bedding in the less competent shaly layers. This overall sigmoidal geometry (Fig. 7a) reflects a component of bed-parallel west-verging reverse shearing (cleavage refraction, see for example Fossen, 2010). Note however that this reverse shearing, although locally subparallel to the Ornon normal fault plane (Fig.7a) should not be taken as evidence for the Alpine reactivation of the inherited Jurassic normal fault (e.g., at depth within the basement). The sedimentary layers, mostly deformed in a coaxial way (Fig. 7b), have however been locally parallelized to the normal fault and may have underwent local shearing without any reverse movement at depth in the basement along the fault plane. Here, the lithological contrast between the cover and the basement likely promoted the localization of the deformation. During the Alpine shortening, the sediments were deformed in the basin and the footwall basement acted as a buttress (see Tricart and Lemoine, 1984). 
At a larger scale, the cleavage is parallel to the fold axial planes (Vialon, 1968). At la Paute (Fig. 7b), tight folds display a sub-vertical axial cleavage and a sub-vertical stretching lineation, attesting for pure shear deformation, with horizontal shortening and vertical stretching. Moving upward structurally, both the bedding (Fig. 6) and the cleavage dip around $50^{\circ} \mathrm{E}$ and the series is overturned. Moving down topographically, the dip tends to steepen. Thus, as shown by Gidon (2001), the folds within the inverted basins are rather steep at depth and overturned and west-verging at shallower levels.

To summarise, close to the inherited Ornon fault, strain is rather coaxial in the lower part of the Bourg d'Oisans basin and shows an increasing non-coaxial component in its upper part, consistent with a west-verging shearing of the entire cover (Fig. 6).

\section{La Garde Thrust and the Huez area}

A component of non-coaxial strain in the sedimentary rocks can be observed north of La Garde (Northeast of Bourg d'Oisans, Fig. 4) (also in Gratier and Vialon, 1980). There, steeply west-dipping fold axial planes (see Fig. 7b in Dumont et al., 2008) clearly indicate eastverging shearing within lower Liassic levels (Fig. 6). This is also clear on the road from Huez to Villard Reculas (Fig. 4) where an east-verging thrust propagation fold is associated to a west-dipping cleavage (Fig. 8a, b). The fold is asymmetric and genetically linked to a small reverse fault that roots in a shaly layer.

This deformational event predates a second one marked by an east-dipping cleavage (S2, Fig. 8). This $\mathrm{S} 2$ cleavage is superimposed on the early structures: veins, linked to the termination of the early east-verging thrust (tail cracks), are offset by faulting along the early planes of cleavage (S1), faulting being consistent with the S2 cleavage (Fig. 8). The geometry of the S2 cleavage (cleavage refraction) supports local shearing within the shaly layers (Fig. $8 \mathrm{c}, \mathrm{d})$. The S1 cleavage is locally opened, the opening being consistent with bed-parallel 
shearing that caused refraction of S2. Thus, again S2 and the associated shearing postdates S1.

The S1 cleavage is clearly associated with an east-verging shear component as it is compatible with the east-verging fault-propagation fold. S2 is, at least locally, associated to a bed-parallel shearing, consistent with the N-S folds with axial planes sub-vertical to eastdipping (attesting west-verging shear component) that were described in the previous section.

The S1/S2 chronology is confirmed in many places (Fig. 9a) where the bedding and an early cleavage S1 are deformed by folds with a steep syn-folding cleavage (S2). In the east-dipping limbs of these N-S folds, the early cleavage dips systematically shallower than the bedding, while in west-dipping limbs, it is steeper but less visible (Fig. 9b). The early cleavage is not associated to any meso-scale fold, as the only visible folds in this area are folds associated to S2. However, the cleavage S1 might be associated to (or is at least compatible with) the eastverging shearing of the cover, as described above (Fig. 8a, b). This event is here followed by a rather pure shear deformation associated to straight and symmetrical N-S folds with subvertical to east-dipping axial planes.

To sum up, two cleavages are observed. A first one, S1, is compatible and probably associated with an early east-verging shearing of part of the cover. The second one (S2) is the main cleavage and is synchronous with folding of both the bedding and S1. Those folds have sub-vertical to east-dipping axial planes and reflect a later west-verging shearing of the cover (Fig. 6).

Those cover deformations are located around the tip of a west-verging thrust/shear zone (Fig. 4 and 6), the La Garde thrust. As shown on the cross section, the thrust has a limited throw of a few tens of meters and it is characterized by shear zones in the basement with west to southwest-verging kinematics. The associated mineralogy is typical of greenschist facies (chlorite, epidote, mica, and also talc). In the hanging wall of these shear zones, the Triassic 
layers are vertical, hence the basement top. Such an attitude implies that a significant amount of deformation is distributed within the basement, and accommodated along anastomosed shear zones separating large, almost undeformed basement blocks that rotated during shearing. During a late stage, this system was offset by a thrust witnessing an ultimate localization of the deformation.

\section{The Col de Cluy shear zone}

Further East, the main observations were made in the basement, mainly due to the overall eastward (toward the crest of the Grandes Rousses tilted block) thinning of the sedimentary sequence (Fig. 4 and 5) and the (related) scarcity of outcrops.

At Col de Cluy (Fig. 4, ESE of the Alpe d'Huez), numerous thick shear zones (Fig. 10) affect the basement with a total thickness of about $500 \mathrm{~m}$. In these shear zones, an Alpine cleavage, synchronous with a greenschist metamorphism, is marked by the occurrence of newly formed chlorite, epidote and white micas. The Alpine age is attested by the overturned (30 ${ }^{\circ}$ east dipping, Cluy shear zone, Fig. 6) attitude of the Triassic layers below the shear zones. Shear zones dip between $30^{\circ}$ and $50^{\circ} \mathrm{E}$, showing that they do not result from the reactivation of either Jurassic normal faults or variscan foliation that dip much steeper (around $70^{\circ} \mathrm{E}$ or more).

Considering the overturned attitude of the Triassic layers and the shearing intensity within the basement, the "basement fold" must have a rather large amplitude (Fig. 6). In such area, it is likely that the Triassic layers are sheared with a similar amount than the basement. Thus, the length of the Triassic layers, beyond the uncertainty of their geometry, must be considered as an upper bound for restoration purposes (see further down).

\subsubsection{The Mizoen basin (northwestern Oisans)}


The structure of the Mizoen basin is similar to that of the Bourg d'Oisans basin. Metasediments have a sub-vertical attitude in the lower part of the basin (Fig. 6) (Gidon, 2001), while the folds are overturned at higher levels, with axial planes dipping about $50^{\circ}$ East.

On the western side of the basin (close to the Jurassic normal fault), the bedding is affected by folds (Fig. 6) and axial-plane cleavage. Bedding and cleavage are in turn affected by westverging shear zones (Fig. 11a), consistent with the large-scale west-verging folds. Triassic layers, attached to the basement, are close to horizontal on the Plateau d'Emparis (Fig. 4) to the East to almost vertical further west (Fig. 6, 14). Above the basement-cover interface that dips westward, east-verging faults and folds can be observed (Fig. 4 and 6). Such an eastverging shearing can also explain bed-parallel shearing attested by cleavage refraction (Fig. 11b).

Summarizing, over the entire Mizoen basin, a steeply dipping syn-folding cleavage is deformed by east- (in the East, close to the basement) or west- (in the West) verging shear zones, attesting for a continuum of E-W shortening and shearing deformation controlled by the basement-cover interfaces.

Further south, at the Plan du Lac (Fig. 6), in a structural position similar to the basement west of the Emparis plateau, the basement is intensely sheared by west-verging shear zones (Fig. 12). These shear zones are similar to those described in the northern Grandes Rousses (Fig. 2 and 3) and the Cluy ones (Bourg d'Oisans basin, Fig. 10). The overall thickness of these zones is about few hundred meters; they have been projected on the cross-section as the Plan du Lac shear zones (Fig. 6).

\subsubsection{Synthesis of field data and interpretations}


In the inverted Jurassic syn-rift basins (Fig. 13a), the Alpine shortening history can be summed up as follows. N-S shortening occurred either before or after Priabonian times (see Dumont et al., 2008; 2011) and is mainly observed in the south of the Oisans massif and mostly characterized by brittle features. This event will not be considered furthermore, since the scope of this paper is to constrain the kinematics of the shortening during (and after) the (E-W) overthrusting of the internal units.

In the area of interest, the main shortening phase was thus oriented E-W. During an early (Oligocene ?) stage, the Oisans massif was underthrusted below the internal zones and shortening produced a pervasive sub-vertical cleavage (Fig. 13b). This cleavage (S1) is locally sigmoidal because of synchronous shearing at the lithological boundaries, i.e. the basement-cover interface (Fig. 13b): east-verging shearing occurred in the Liassic rocks close to the west-dipping basement-cover interface (in both basins). Basically, the sense of shear is controlled by the dip of those inherited discontinuities. During this stage, the basement might have started to deform (although not represented on Fig. 13b, see discussion).

During a second (late Oligocene-early Miocene?) stage, in a continuum of E-W shortening, the cleavage S1 still developed during folding of the cover rocks (Fig.13c). In the deep parts of the basins, the folds are straight and symmetric, the cleavage is parallel to fold axial planes and is oblique at low angle to bedding in the fold limbs: there, only one population of cleavages is observed (Fig. 13c: D). Locally, the cover is deformed over short décollements. The deepest parts of the basins also display cleavage planes steeply dipping to the west that support an east-verging shear component (i.e. as in the earlier phase, see for example the Bourg d'Oisans folds, Fig. 6). In the shallower central part of the basins, the east-dipping axial planes of the folds indicate a clear west-verging simple shear, due to the overthrusting of the internal units (Fig. 13c: C). 
Close to inherited normal faults, the cleavage pattern remained unchanged and is still controlled by the lithological contrasts (Fig. 13c: A). Close to the basement-cover interface, in the eastern parts of the blocks, a S2 cleavage associated to west-verging shearing is superimposed to S1 (Fig. 13c: B). There, the two cleavages are clearly different, while in many other structural positions they cannot be distinguished ( $\mathrm{S} 1 / \mathrm{S} 2$ in Fig. 13c). Interestingly, those results show that the cleavage pattern that develops during a deformation stage may strongly depend on the location within the inverted (inherited) basin.

\subsection{Regional cross section and restoration}

The main shortening being oriented E-W, we built an E-W cross-section at the scale of the whole External Alps. From West to East, the cross section (Fig. 14) shows the Vercors folded belt, the southern Belledonne, the southern Grandes Rousses and the northern Oisans massifs. This location has been chosen as it optimizes the outcrops of Triassic layers required to reliably estimate crustal shortening, the Triassic quartzites and dolomites still attached to the basement providing a good marker of its Alpine deformation. Three basins can be recognized along the transect from West to East: the Grenoble, the Bourg d'Oisans, and the Mizoen basins. Their thickness is decreasing eastwards.

The cross-section was balanced using constant lengths and areas for the Mesozoic strata in the subalpine chain (Deville et al., 1994). In the ECM, the section has been balanced using constant length for Triassic layers and constant surface for Jurassic strata (Liassic and Dogger) as the Jurassic layers were strongly deformed (length variation, see Fig. 5 and below). However, the Triassic layers might have been lengthened as, in the shear zones, they were sheared (as in Col de Cluy and deep part of the Mizoen basin, for example, see above). As they were rotated during shearing, and under the assumption of a shear zone with constant 
thickness (FIG, which may not be the case), they probably underwent shortening first and then lengthening, especially when it got overturned.

The overestimate is probably maximum at the Col de Cluy area as we observed shallowly east dipping overhanging Triassic layers. The length of the overhanging flank is about $2 \mathrm{~km}$ long, while it might have been only $1 \mathrm{~km}$ long: if we consider that the length of this flank was approximately similar to the "horizontal thickness" of the shear zone (FIG), thus the overestimate is about $1 \mathrm{~km}$.

In the deepest part of the inherited basin (close to the Ornon and Mizoen paleo-normal faults), the Triassic layers length might in turn have been underestimated, as during the initial shearing of the layer its length decreased (FIG). The underestimate might reach few hundreds of meters. Thus, over the entire zone, the shortening is most likely estimated with an error bar of less than $+/-500 \mathrm{~m}$.

The western part of the section has been redrawn from Deville et al. (1994). Below the folded belt, the décollement of the cover lies within the marly Liassic layers. It dips eastward and deepens from 4 down to $7 \mathrm{~km}$. Three main thrusts deform the folded cover and root in the décollement; they were activated during the formation of frontal crustal ramps (Menard et al., 1979; Deville et al., 1994). The shortening in this part of the belt is about $10.5 \mathrm{~km}$. Shortening in the folded belt being likely due to the activation of a frontal crustal ramp (Deville et al. 1994; Deville and Chauvière, 2000), its amount can be used to constrain the throw along this ramp.

The movement at the cover-basement interface in the eastern part of the basin is attested as a backthrust (Deville et al., 1994). However, its amplitude had never been estimated. Considering the large thickness of Mesozoic sediments and their thickening toward the Belledonne massif, we followed the interpretation of Deville et al. (1994) of a normal fault bounding the western Belledonne massif. However, the throw of this normal fault at depth 
directly controls the displacement along the subsequent backthrust. The very large displacement normal fault presented in Deville et al. (1994) maximizes the backthrust throw. We have chosen an alternative geometry with a smaller throw along the west-dipping normal fault and the occurrence an antithetic normal fault, which minimizes the backthrust throw as well as the normal fault initial throw. Thus, the geometry of the resulting basement triangle zone below the normal faults has been slightly changed compared to Deville et al. (1994). The amount of shortening accommodated by the second crustal thrust in the basement and the associated deformation of the cover (including the backthrust) is about $6 \mathrm{~km}$.

In the central part of the section (Bourg d'Oisans and Mizoen basins, Fig. 6 and 14), the precise geometry has been described in the above sections. In the basement, shear zones and thrusts accommodate shortening. In the cover, disharmonic folds are observed, with only short and local décollements. There is a slight west-verging shearing at the base of the sedimentary cover but it does not imply that a décollement was activated all over the studied area.

The normal throws of the Liassic normal faults were kept unchanged in agreement with the lack of evidence of inversion (see sections 3 and 4). Thus, the sediments were not strongly horizontally displaced relatively to their basement: the syn-rift sediments still lie in their own pre-orogenic basin. The size of the syn-rift basin was inferred from the normal fault throw and the restoration of the Triassic layers. Their initial length was used and restored considering an initial dip of the basement top that has been estimated to about $10^{\circ}$, consistently with the dip recognized in non-inverted rifts with similar normal fault throw (e.g. the Gulf of Suez in Colletta et al., 1988).

Under these assumptions, the crustal shortening in this central area was estimated to $11.5 \mathrm{~km}$ (i.e. about $20 \%)+/-0.5 \mathrm{~km}$. The Liassic layers in the ECM can be much longer than the Triassic ones (Fig. 6) and this should suggest a strong décollement. However, the structural 
analysis shows that there is no major décollement (Fig. 6); this excess of shortening of the Liassic layers can be explained by their internal lengthening (up to few hundred percents) as observed in the field (Fig. 5c).

Finally, east of Emparis plateau, the cross-section has been drawn from Barbier et al. (1973). Because of their small spacing, the thrusts have been rooted in a shallow décollement layer at the base of the Mesozoic (either Triassic or lower Liassic layers). Moreover, there is no basement outcrop in this area (except in the Grand Chatelard, which is further North, and in the Meije and Combeynot massifs that are south of the Romanche valley that most likely represents a transfer fault), suggesting that the basement was not involved in shortening. It is therefore noteworthy that the cover is shortened over a décollement in areas devoid of any thick inherited syn-rift basin. There, the basement was not shortened and a décollement within the marly Liassic layers was activated.

\section{Discussion}

\subsection{Basement-cover coupling in the external crystalline massifs of western Alps}

\subsubsection{Basement deformation}

Large-scale structural observations in the northern Grandes Rousses (Fig. 2 and 3) and the northern Oisans (Fig. 10 and 12) demonstrate that "basement folding" is associated with, and likely accommodated by, distributed shear zones within the basement (Fig. 15). This basement deformation is clearly Alpine in age since these shear zones affect Variscan units but also Triassic layers, that are sheared, folded, and even overturned in some places; their kinematics is consistent with the E-W Alpine shortening and associated deformation (Malavieille et al., 1984), at least for the main west-verging kinematic event.

Detailed field observations indicate that the basement rocks deformed in a brittle-ductile regime. This is supported by microscopic observations and the distribution of shear strain 
within few hundred-meter thick shear zones (Fig. 3 this paper; and Simon-Labric et al., 2009). This is in accordance with the maximum estimated temperature, slightly above $300^{\circ} \mathrm{C}$ (Crouzet et al., 2001), related to a tectonic burial (see further down) of about 10km (Fig. 15b).

Some basement rocks provide evidence for cataclastic deformation (Fig $\mathbf{3}$ and in Wibberley, 1999). This behaviour can be explained either by a shallower tectonic burial (as in the southern part of the massif) or by strain localization during tectonic exhumation due to the displacement along the thrust/shear zones. Thus, the late/last increment of deformation along such structures may have occurred at shallower depth in conditions typical of brittle deformation (usually below $300^{\circ} \mathrm{C}$ for granitic rocks).

From a kinematical point of view, Dumont et al. (2008) suggested that the basement thrusts in the Oisans-Grandes Rousses massifs result from the reactivation of the steep Variscan foliation; this is in poor agreement with our observations that the shear zones dip much shallower than the foliation. Alternatively, Butler et al. (2006) suggested that basement deformation might be due to the buckling of the upper crust characterized by lithology contrasts (especially the basement-cover interface). If the initiation of the deformation by buckling cannot be ruled out, shortening is most probably not only due to this mechanism: the spacing of the deformed zones (few hundreds meters to few $\mathrm{km}$ ) is too small to be controlled by buckling. In addition, the preferential westward vergence of the shear zones does not support a buckling mechanism that would have implied a rather pure shear deformation, at least at its initiation.

In the Oisans massif and its surroundings, the basement shear zones are mainly west-verging (Fig. 6 and 12). However, Marquer (1990) in the Gothard massifs and Marquer et al. (2006) in the Belledonne massif showed that the shortening is mainly accommodated by pure shear, with sub-vertical cleavage and steep associated "conjugate" reverse shear zones. In Burkhard 
(1988) however, it seems clear that shortening in the Aar massif has been instead accommodated by west-verging shear zones considering the dip of the axial planes of the basement folds and the shear zones described in Choukroune and Gapais (1983). In this massif, Rolland et al. (2009) recently showed that the top-to-the-north shearing has been accompanied by a large pure shear component and has been followed by right-lateral shearing. In Gourlay (1986), Leloup et al. (2005) and Rolland et al. (2007, 2008), the deformation features in the Mont Blanc massif also consist of west-verging shear zones, even if there is also a significant number of east-verging ones (with an oblique shear component), implying a pop-up-like structure. As a result, alpine collisional shortening in the external crystalline massifs was accommodated along-strike either by dominant coaxial (Belledonne, Gothard) or non-coaxial strain (Oisans, Grandes Rousses, Mont Blanc, Aar), the control on which of these modes prevails being still poorly understood.

\subsubsection{Internal strain in inverted syn-rift sedimentary basins}

From a general point of view, the amount of strain in the inverted basins (Fig. 5) is high (sub-vertical stretching). Such pervasive deformation supports the interpretation that the normal faults were not reactivated, but rather acted as buttresses (Tricart and Lemoine, 1984; Butler, 1989). This is in accordance with our observations that neither the Variscan foliation nor the Liassic normal faults were significantly reactivated. It is also in agreement with numerical models (Buiter and Pfiffner, 2003) that show that the presence of weak syn-rift sediments tend to inhibit normal fault reactivation, at least at the surface, and to promote the initiation of short-cut basement faults. Note that such short-cuts (Butler et al., 2006), although kinematically viable, could not be documented in our study.

In details, two main stages of deformation of the Liassic cover were recognized during E-W shortening. The first stage is associated with moderate strain and the development of a sub- 
vertical cleavage associated to local, top-to-the-east shearing in the lower part of the basins, i.e., close to the west-dipping basement-Triassic interface (Fig. 13b). These deformations are clearly driven by the orientation of the lithology contrasts: in the inherited syn-rift basins, the west-dipping basement top was suitably oriented to accommodate (and even promote) eastverging shearing. These east-verging shear structures were already observed, although at a larger scale, by Gillcrist et al. (1987) and Butler (1989) and are illustrated on our crosssection (Fig. 6). Such "back"-shear has also been mapped out in other inverted basins such as in the Spanish Pyrenees (see for example Saura and Teixell, 2006).

This early E-W shortening of the Liassic layers was probably contemporaneous with slight basement deformation, such as recently documented early Oligocene (31-34 Ma) strike-slip conjugate shear zones kinematically consistent with E-W shortening (Simon-Labric et al., 2009). Accordingly, in our conceptual model (Fig. 13b), the horizontal shortening of the basement induced first east-verging shear on the west-verging basement-cover interface in an overall pure shear configuration. In contrast to Dumont et al. (2008) who interpreted the eastverging shearing component of deformation as a late stage, we rather interpret it as early since the cleavage consistent with the top-to-the-west kinematics (main phase) clearly postdates the development of cleavage compatible with top-to-the-east shearing (Fig. 8 and 9).

The second deformational stage is associated with large strain with a mix of coaxial and non-coaxial strain depending on the location within the basin (Fig. 13c). This phase is coeval with crustal thickening and emplacement of internal units. These deformations in the cover likely occurred before $26 \mathrm{Ma}$ (Crouzet et al. 2001) at rather high temperature (around $300^{\circ} \mathrm{C}$ ).

Finally, there might have been a late shortening event that locally caused east-verging shearing (D4 in Dumont et al., 2008), but also west-verging shear, or pure shear deformation as suggested in Gratier and Vialon (1980). We do not consider it as a new deformation stage 
but rather as the end of the continuum of E-W shortening that locally overprinted earlier deformations.

\subsubsection{Amount of shortening, basement-cover coupling and sequence of deformation}

At the latitude of our cross-sections, nearly all structures are consistent with an E-W shortening. The amount of E-W shortening (11.5 km for the ECM, $16.5 \mathrm{~km}$ for the folded belt) derived from our restoration is significantly less than that in Beach (1981), Butler (1983), and Menard and Thouvenot (1987) for the same area. However, our estimate is based on a detailed study of the basement-cover interface, which is probably the best proxy for crustal shortening estimates. On the contrary, the amount of shortening is slightly higher than in Dumont et al. (2008), which is mainly due to their interpretation of the reverse faults and shear zones as reactivated steep variscan foliation planes. As a consequence the estimated amount of shortening, on such steeply dipping structures, was likely underestimated. Our estimates are in good agreement with those of Mugnier et al. (1990) of 35 to $50 \mathrm{~km}$ for the Belledonne massif.

As attested by the large shear zones described in this contribution, the ECMs, and especially the Oisans, Grandes Rousses and Belledonne massifs, deformed in a relatively distributed way (Fig. 15). The age of basement deformation in the Oisans-Grandes Rousses massifs is not well constrained. Simon-Labric et al. (2009) showed that strike-slip shear zones were 31 to 34 Myrs old, but no age for thickening is available. These authors showed that some recrystallisation occurred until $27 \mathrm{Ma}$ (also during strike-slip deformation), which may suggest that either only brittle faulting occurred since that time (that may explain some alteration in the LT part of the Ar spectra, Simon-Labric et al., 2009) or deformation occurred on other shear zones, such as the reverse ones described here. 
In other ECMs, such as the Mont Blanc and the Aar massifs, crustal shortening started at least at $22 \mathrm{Ma}$ (Leloup et al., 2005, Rolland et al., 2008, Challandes et al., 2008). In the southern ECMs, the Argentera-Mercantour massif, the deformation ages in shear zones range between $33 \mathrm{Ma}$ and $20 \mathrm{Ma}$ (Sanchez et al., 2011). Thus, one can consider that basement deformation in the Oisans-Grandes Rousses massifs is Oligocene-early Miocene in age. The deformation subsequently localized on the frontal ramp that activated the folded belt (Fig. 15). This ramp activation is dated by the early Miocene folded molasse of the subalpine chain (Philippe et al., 1998) as well as by middle Miocene exhumation ages in the ECM (see the synthesis in Vernon et al., 2008).

This contribution mainly focuses on the first (Oligo-miocene) phase of distributed deformation in the crystalline massifs. The extent at depth of the basement shear zones is poorly constrained. They may root at the brittle-ductile transition (Burkhard and Sommaruga, 1998; Ford et al., 2006; Lardeaux et al., 2006) or deeper implying lower crust duplexes (Roure et al., 1990; Schmid et al., 2004) or even Moho offset (Bois et al., 1990).

At the surface, on our cross-sections (Fig. 6, 13, 14), there is no major décollement of the cover over the basement. The syn-rift rocks were strongly deformed but are still located in their original basin (Fig. 15b). This means that there was no major translation of the cover above the basement and thus that there is no major phase of thin-skinned tectonics.

However, thin-skinned tectonics can be inferred at certain times and places along the crosssection:

(i) Below the internal units (and the Tertiary flysch) in the eastern part of the section, the cover has been strongly deformed (Fig. 14), most probably in Oligocene times. It is affected by several closely spaced thrusts, which indicates that such structures are likely due to a shallow décollement in the lower Liassic rocks. In addition, in this area, there is no basement outcrop, which therefore appears much less deformed than further South (Meije and 
Combeynot thrusts). In this case, the décollement was presumably activated because no or few deformation occurred in the basement. It is noteworthy that there is no thick inherited syn-rift basin in this area (Trift and de Graciansky, 1988). This suggests that the whole crust was shortened mainly below inherited syn-rift basins (see further). As a comparison, northeast of the Mont Blanc massif, the Diablerets and the Wildhorn nappes (sedimentary nappes) were emplaced above the Morcles nappe (see Burkhard and Sommaruga, 1998, and references therein) over a large distance, suggesting thin-skinned tectonics. Based on the available reconstruction (Burkhard and Sommaruga, 1998), the Diablerets and Wildhorn nappes are interpreted as the cover of a non-thinned crust.

(ii) In the shortened inherited syn-rift basins, the cover is disharmonically deformed over basement folds (Fig. 6). However, in specific areas, such as the footwall of some basement shear zones, it is deformed above a short décollement (in the lower Liassic strata, Fig. 6). This is due to particular structural setting and, from a general point of view, thick-skinned tectonics still prevailed in the inverted inherited basins.

(iii) Finally, in the subalpine chains or in the Jura, the basement is much less shortened. A décollement is activated in the lower Liassic or Triassic rocks (see for example, Deville et al., 1994; Philippe et al., 1998, Affolter et al. 2008 and references therein). There, the crust has not been tectonically buried and was rather thick and strong (proximal-most part of the margin). However, in those outermost parts of orogens, thick-skinned tectonics can also occur below the Jura (Mosar, 1999; Lacombe and Mouthereau, 2002) or in the Provence (Roure and Colletta, 1996).

Summarizing, Alpine collisional the shortening was clearly thick-skinned in the OisansGrandes Rousses with deformations rather distributed throughout the basement during Oligocene (and Miocene?) times. At mid-Miocene times, the deformation localized along the 
frontal crustal ramp that activated the folded belt, while the ECMs were quite passively exhumed above the ramp.

\subsection{Implications for the rheology of crustal collisional wedges}

\subsubsection{Role of the inherited normal faults}

At the present-day surface, the structures accommodating shortening are typically shear zones (or thrusts) dipping between $30^{\circ}$ and $50^{\circ}$ East (Fig. 2 to 5, 10, 12, 15). Although it was often proposed that in the ECM basement thrusts result from reactivated normal faults (see for example, Hayward and Graham, 1989; Gillcrist et al., 1987), there is no field evidence to support a significant reverse reactivation on the inherited Liassic normal faults, as suggested by Butler et al. (2006). The main faults (Ornon and Mizoen normal faults) still have a large normal offset (few $\mathrm{km}$ ); this may suggest that there was no significant reactivation. On the Ornon fault, the few evidences of some reverse shearing of the Liassic rocks are only due to lithology contrasts (see Tricart and Lemoine, 1984) between the basement footwall (that acted as a buttress) and the cover hangingwall, and by no means imply that the fault has been significantly reactivated at depth.

There is basically no steeply dipping $\left(60\right.$ to $\left.90^{\circ}\right)$ shear zones or thrusts in the basement; this strongly suggests that compressional structures do not correspond to either ancient normal faults or to steep Variscan foliation. In areas similar to the Oisans-Grandes Rousses massifs, the normal faults are very often seen as not reactivated (Lemoine et al., 1986, Gillcrist et al., 1987, for the Mont Blanc massif; Badertscher and Burkhard, 1998, for the Aiguilles Rouges massif; Butler, 2006, 2007, for the Caledonian Moine thrust belt). This is most probably due to the $\mathrm{P}, \mathrm{T}$ conditions (greenschist facies), related to tectonic burial. In the underthrusted crust, the normal faults have an internal strength that is lower than that of the basement rocks, but higher than the strength of the crust with the inherited basin (see further down and Fig. 15b). 
Butler et al. (2006) proposed that normal faults were reactivated only in the outermost parts of the Alpine orogen. Normal fault reactivation effectively occurred in many external folded belt worldwide (Letouzey, 1990): in the Zagros folded belt (Jackson, 1980; Mouthereau et al., 2006), in Taiwan (Mouthereau and Petit, 2003; Lacombe and Mouthereau, 2002; Mouthereau and Lacombe, 2006), in the Jura (Burkhard 1998; Lacombe and Mouthereau, 2002, Philippe 1995, Pfiffner et al., 1997), in Provence (Roure and Colletta, 1996), in the southern Pyrenees (Saura and Teixell, 2006), in the Laramide Rocky Mountains (Marshak et al., 2000), and in the Sierras Pampeanas (Cristallini and Ramos, 2000). In those outermost orogenic domains, the crust experienced no significant tectonic burial. The deformation occurred close to the surface and, in those conditions, the reactivation of normal faults and their inversion are mechanically possible (Fig. 15a) as there is a high strength contrast between the (strong) crust and the (weaker) internal fault zones.

Of course, in the underthrusted crust, the normal faults may have been reactivated at depth as suggested by Butler $(1989,2006)$. Their likely low dip at depth when approaching the brittle-ductile transition may have been suitable for reactivation and short cut geometries may be relevant for the ECM. Indeed, the strength envelopes, at depth (below 15km), are similar for the basement, the inherited basins, and the inherited normal faults (Fig. 15b). If short cuts have been documented in the outermost parts of orogens (see for example Roure and Colletta, 1996), they however still need to be demonstrated for ECM regions.

\subsubsection{Role of inherited syn-rift basins}

Although the normal faults were most probably not reactivated, our study clearly suggests that inherited Jurassic syn-rift basins localized later contractional deformation. Indeed, the main basement shear zones are localized below the inherited syn-rift basins (Fig. 15b). In the Aar massif (Burkhard, 1988; Challandes et al., 2008) and the Mont Blanc massif (Ramsay, 
1981; Epard, 1986; Escher et al., 1988; Burkhard and Sommaruga, 1998), the deformation in the basement was also localized below an inherited syn-rift basin and the sedimentary nappes originated from the cover of this basin even though the bounding normal faults were not reactivated.

Thus, it appears that syn-rift basins localized later collisional shortening, even if the normal faults did not play a significant role. Simple considerations of strength of faults, Liassic cover, and basement rocks (Fig. 15b) show that the basin had a much lower internal strength than that of the inherited fault zones. The syn-rift sediments (few $\mathrm{km}$ thick) buried below approximately $10 \mathrm{~km}$ of internal units had a ductile behaviour while the fault and the basement were still brittle and thus more resistant. The weakening effect of the inherited basins (Fig. 15b) therefore localized the shortening within these basins.

\subsubsection{Role of tectonic burial and temperature}

The burial and associated increase of temperature has been suggested above as being responsible for the non-reactivation of the inherited normal faults and the localization of the shortening in the inherited syn-rift basins. We here discuss the consequence of tectonic burial on the shear zone thickness.

The shear zones affecting the basement are relatively thick. They are few tens to hundred meter thick and they accommodate shortening of about few hundred meters. Under low-grade metamorphic conditions, the displacement along shear-thrust zones is usually larger than the thickness (see Wibberley (2005) for a synthesis of shear zones displacement vs. thickness relationships). This is commonly explained by weakening processes such as feldspar alteration and retrogression into phyllosilicate-dominated rocks (Wibberley, 1999). In such a case, the thrust zone initiated within the cataclastic flow regime and evolved into a mylonite and ultramylonite. As a consequence the deformation is rather localized. Such structures were 
recognized in the Moine Thrust Belt or in southern Oisans (Wibberley, 2005), where the temperature was probably lower than in northern Oisans as suggested by Zircon fission-track thermochronology (Vernon et al., 2008).

The large thickness of the shear zones described in this contribution might be explained by the low strength of the crust and its ductile (or brittle-ductile) behaviour below $10 \mathrm{~km}$ of tectonic burial that heated up the crust thanks to a relatively fast thermal relaxation (few Ma, Crouzet et al., 2001). Additionally, significant syn-kinematic strain hardening might have occurred, as inferred by Wibberley (1999) from microstructural evidence, because the (early) destabilization of feldspar led to cementation of the deformation zone by the released silica. In such case, the internal strength of the shear zone is increased. However, this hardening is followed by strain softening (Wibberley, 1999) that has also been observed in other ECMs (see Oliot et al., 2010 for the Gotthard massif). Thus, strain hardening alone most probably does not explain the thick shear zones.

Similar geometries have been mapped out in the Caledonide Moine Thrust Belt (Barber, 1965 cited in Butler et al., 2006b and Butler, 2010). It is noteworthy that these shear zones are located in the footwall of the Moine Thrust and thus experienced significant tectonic burial (lower greenschist facies). In the southern part of this belt, where those thick shear zones are observed, large-scale folding of the basement-cover interface is witnessed by recumbent structures (Stewart, 2002; Butler, 2010). Moreover, it is suggested that those distributed basement shear zones have evolved as major basement thrusts (Butler et al., 2006b).

In the Mont Blanc massif (Fig. 1), the shortening is accommodated by very thick shear zones (several hundreds of meters) (Leloup et al., 2005, Rolland et al., 2008). Those shear zones are more numerous and thicker than in the Oisans massif and there, the maximum Alpine temperature was about $400^{\circ} \mathrm{C}$ (Rolland et al., 2003). In the Aar massif, several shear zones (also much more numerous than in the Oisans massif) were described (Choukroune and 
Gapais, 1983) and the basement top is highly folded (Burkhard, 1988). In this massif as well, the maximum temperature is about $450^{\circ} \mathrm{C}$ (Challandes et al., 2008).

There is therefore a likely link between the ability of the basement to deform by folding and the associated distributed shear zones and the P-T conditions prevailing during its shortening. The hotter the $\mathrm{P}, \mathrm{T}$ conditions, the more distributed the deformation. The relative amount of shortening accommodated by "basement folding", with respect to the total shortening, can thus be taken as an indicator of crustal rheology, interpreted as a consequence of either hardening (in the shear zones) due to mineralogical transformations or softening (of the whole crust) due to burial and associated increasing temperature.

\subsubsection{Crustal strength and collision dynamics}

Distributed upper crustal brittle-ductile deformation is rather typical of a weak crust at the time of collisional deformation. In the western Alps, the thermal age of the lithosphere was relatively young at the time of shortening (i.e. around $150 \mathrm{My}$, between $180 \mathrm{Ma}$, Lemoine et al., 1981, age of the rifting, and $30 \mathrm{Ma}$, age of the collision). During Jurassic times, the crust has thus been slightly thinned and heated. Related reduction in crustal thickness and buoyancy allowed significant tectonic burial, driven by slab pull, below the internal zones. The associated $\mathrm{P}, \mathrm{T}$ conditions favoured a thick-skinned deformation (i.e. a shortening of at least the whole upper crust) during collision, since the overall strength of the crust buried at approximately $10 \mathrm{~km}$ depth was lowered (Fig. 15a,b). The thick-skinned style is also largely influenced by the presence of weak inherited syn-rift basins that favoured basement deformation by also decreasing the crustal strength (Fig. 15b).

Numerical modelling by Burov and Yamato (2008) showed that hot lithospheres were less prone to stable subduction and ultra high-pressure metamorphism than cold ones. Indeed, in the external Western Alps, the Jurassic crustal thinning was not large enough or old enough to 
allow a real subduction of the crust down to large depth and high-grade metamorphism conditions, such as in the internal zones. For comparison, in Taiwan, where the thermal age is much younger, about 30Ma, Yamato et al. (2009) recently suggested that the crust was too buoyant to undergo significant tectonic burial. This context may thus represent an endmember. Despite this, in the southern part of the island, the crust is still deformed in a thickskinned style, which suggests a weak crust (Mouthereau and Petit, 2003). Thus, this weak crust cannot be explained by tectonic burial and associated temperature. In such case, the geotherm of this hot $\left(800^{\circ} \mathrm{C}\right.$ at Moho depth) lithosphere associated to inherited weak faults are enough to weaken the crust and promote its shortening.

\section{Conclusions}

In this contribution, we have built two new cross-sections in the external part of the western Alps at the latitude of the South Belledonne-Grandes Rousses-Oisans massifs. These crosssections, together with new field data, show that the inherited structures such as Variscan foliation and Jurassic normal faults were not significantly reactivated during collisional shortening. Reactivation may have occurred in some places but, based on our field observations, this was not a common mechanism of crustal shortening.

The newly created structures, in the basement, are mainly reverse shear zones distributed along large thickness, in the order of tens to hundreds of meters. This kinematics is responsible for the "basement folds" observed in these areas. Shortening mainly occurred below the inherited Jurassic basins. Those basins (but not their bounding normal faults) played a great role in localizing shortening. This deformation most probably occurred during Oligocene (to early Miocene?) times and account for $11.5 \mathrm{~km}$ of shortening. In the inverted basins, the cover is mainly disharmonically folded above the basement (thick-skinned style), rather than shortened and displaced over a regional décollement. On the contrary, where there 
was no inherited basin, the basement is not shortened and the cover is strongly deformed above a décollement (thin-skinned style).

There has been a progressive localization of the deformation that evolved from brittleductile to brittle and from the inner to the outer parts. At middle Miocene times, shortening localized on the frontal crustal ramp; it is estimated to around $16.5 \mathrm{~km}$. The total shortening can thus be estimated to about $28 \mathrm{~km}$ and will constrain future paleogeographic reconstitutions.

Finally, these structural style and sequence suggest that the crust was thinned enough (during Jurassic times) to experience significant underthrusting below the internal units (during Tertiary times), down to around $10 \mathrm{~km}$. The associated P,T conditions (greenschist facies) and the presence of weak syn-rift basins enhanced crustal shortening and favoured a thick-skinned structural style.

\section{Acknowledgements}

The authors would like to thank Mary Ford for discussion and suggestions for this field study in the Western Alps. We would also like to thank François Négro, Philippe Agard, Loïc Labrousse, C. Vautier, and T. Baudin for constructive discussions and/or help in the field, and M.O. and X. Gonord for their warm welcome. Reviews by Y. Rolland and two anonymous reviewers greatly improved this contribution. This work was funded by the "Failles, Fluides, Flux” program of the INSU-CNRS, the BRGM contract L10 U 044, and iSTeP funds.

\section{Figure caption}

Figure 1: Simplified geological map redrawn after Kerckhove et al. (1980) and Debelmas et al. (1980). Two insets show the location of Fig. 2 in the northern Grandes Rousses and Fig. 4 
in the Southern Grandes Rousses and northern Oisans. Straight lines show the location of the cross sections in Fig. 3 and 6.

Figure 2: Field data in northern Grandes Rousses (see Fig. 1 for location). a) Geological map of the northern Grandes Rousses modified from Barbier et al. (1977) with structural data showing vertical cleavage especially in the eastern basement dome, evidence for non-coaxial shear component close to the syncline in Liassic strata (shear zones), and stretching lineation orientation measurements. Circles with letters indicate the locations of thin sections in Fig. 3 where the shear indicators are illustrated. b) Section of the northern Grandes Rousses. The decrease of the spacing between the shear zones (dipping about $50^{\circ} \mathrm{E}$ ) indicates an increasing amount of shearing close to the syncline in Liassic strata. Note that the normal fault has not been inverted. Circles with letters indicate the locations of thin sections in Fig. 3. On the section, only one of the three existing western (small) normal faults has been represented. c) Alpine shear zones on polar projection net with poles of plane isodensity contours. Blue trace: mean plane. d) Alpine cleavage on polar projection net with poles of plane isodensity contours. Blue trace: mean plane. Note that there are sub-vertical cleavages and east-dipping ones. Small red circles represent stretching lineations.

Figure 3: Structural features. a) Photomicrograph of thin section (XZ plane) of the Stephanian magmatic rocks of the northern Grandes Rousses far away from the syncline in Liassic strata. Note the poorly developed Alpine schistosity. Location on Fig. 2. b) Photomicrograph in crossed polars c) Shear zones and d) Photomicrograph in crossed polars of thin-section of the basement rocks of the northern Grandes Rousses close to the syncline of Liassic strata. Note the Alpine shear zones and the sigmoidal Alpine cleavage. Location on Fig. 2. e) Ultra-mylonite/cataclasite and f) Photomicrograph in crossed polars of the basement 
rocks of the northern Grandes Rousses section closer to the syncline of Liassic strata than in c). See location on Fig. 2.

Figure 4: a) Geological map of the southern Grandes Rousses/northern Oisans area (see Fig. 1 for location), modified from Barféty et al. (1973) and Barbier et al. (1973). Each inherited Jurassic basin (Bourg d'Oisans and Mizoen) is deformed by a number of shear zones both on the basement and the cover. b) Alpine cleavage in the Liassic rocks in various places. The cleavage mainly dips toward the East. c) Alpine shear zones in the basement rocks. Their dip ranges between $20^{\circ} \mathrm{E}$ and $60^{\circ} \mathrm{E}$. d) Alpine cleavage in the basement rocks. Their dip is around $60^{\circ} \mathrm{E}$, which is close to that of the variscan foliation. Red circles represents stretching lineations.

Figure 5: Strain markers of (E-W) shortening in marly Jurassic (Liassic and Dogger) rocks.

a) Photo in XZ plane: stretched veins parallel to the main (sub-vertical) cleavage. b) Photo in $\mathrm{XZ}$ plane: pressure shadows around pyrite (in a sub-vertical cleavage). c) Photo in XY plane (sub-vertical cleavage): stretched belemnite, roughly E-W.

Figure 6: Cross-section (location on Fig. 1 and 4) of the Bourg d'Oisans and Mizoen basins after field data and the geological map (Barféty et al., 1973; Barbier et al., 1973). Note the two inherited basins (Mizoen and Bourg d'Oisans), the shear zones in the basement dipping around $50^{\circ} \mathrm{E}$, the folds in the cover with axial planes mainly dipping East, except in few places (sub-vertical to West dipping). For the upper Jurassic, no details are represented, as its outcrops are too scarce. The normal faults were not reactivated. The length of Liassic and Dogger layers that have been eroded cannot be precisely determined. However, those layers have been tentatively drawn. "Detached Liassic" is a unit above the Emparis Plateau that 
roots further East. The internal units are represented only by their basal contact, namely the Frontal Penninic Thrust.

Figure 7: Western part of the Bourg d'Oisans basin. a) "Col d'Ornon" outcrop: Liassic rocks present a steep Alpine cleavage affected by west-verging shear zones (cleavage refraction) localized in shaly layers. A vein (arrow) is stretched and sheared. b) "La Paute" outcrop: Liassic layers are deformed by large folds characterized by a sub-vertical axial cleavage.

Figure 8: The La Garde-Huez area. a) East-verging fault propagation fold in the Liassic rocks with west-dipping cleavage (S1). This fold, the fault and the associated tail cracks (b), are deformed by a west-verging shear attested by an east-dipping cleavage (S2). Shearing along S1 offsets the tail crack and thus postdates the fault, and then the fold and the associated cleavage S1. The cleavage S2 is compatible with a west-verging shear. Moreover, this S2 cleavage (c) opened S1 planes (d). The opening is also compatible with a west-verging shear.

Figure 9: The La Garde-Huez area. a) N-S folds with sub-vertical axial cleavage (S2) deforming an earlier west-dipping S1 cleavage that formed at relatively low angle to bedding. b) Zoom of the previous outcrop. S1 cleavage is oblique at low angle to bedding, with the same attitude relatively to bedding on both limbs of the folds (attested by the bedding curvature). S2 (axial plane of SI and bedding folds) overprinted S1 and thus postdates it.

Figure 10: The Col de Cluy shear zone. a) West-verging shear zones in the basement. Note the regular spacing of zones of intense shearing that bend the Alpine cleavage. b) Detail of a zone of intense shearing. Chlorite-rich basement rocks present a steep East-dipping Alpine 
cleavage and relatively low angle ( 30 to $\left.50^{\circ} \mathrm{E}\right)$ west-verging shear zones. The Alpine age of these shear zones is attested by the overturned attitude of the Triassic strata just west of the area (see Fig. 4 and 6)

Figure 11: Mizoen basin. a) West-verging Alpine shear zones in the Liassic rocks. Note the steep East-dipping cleavage and veins. Those shear zones are small and distributed in the western part of the shortened basin. The bedding, the cleavage, and the veins are sub-parallel and deformed by the shear zones. b) East-verging shear zones localized at shaly interfaces. Those zones are located only in the eastern part of the basin, close to the Emparis Plateau and the Triassic rocks (see Fig. 6).

Figure 12: Plan du Lac basement shear zones. This area is located South of our studied area but is in the lateral southern continuation of the steep Triassic strata west of Emparis (see Fig. 4 and 6). a) and b) Note the large shear zones dipping around $50^{\circ} \mathrm{E}$ and the steep cleavage. West of this place the Triassic strata are steeply dipping, suggesting an Alpine age for deformation.

Figure 13: Schematic representation of cleavage development in Liassic rocks. a) Inherited syn-rift configuration. The basin is west-dipping and controlled by an east-dipping normal fault. b) A first phase of shortening deformed the cover. A sub-vertical cleavage could have formed. Near the lithology contrasts, shear zones localized: close to the lower part of the cover (above the Triassic strata) east-verging shear developed as the interface is west-dipping. This phase could be synchronous with slight deformation in the basement (early Oligocene ages of strike-slip shear zones in Simon-Labric et al., 2009). This early basement deformation is however not represented as difficult to constrain. The only places where it has been 
observed (Simon-Labric et al., 2009), it is of strike-slip type, thus, impossible to represent on a vertical E-W section. c) A second phase of shortening is contemporaneous with large deformation in the basement. The inherited basins are strongly shortened. Various configurations can be found depending on the structural location in the basin: close to the normal faults, shear zones and cleavage developed (S1 and S2 cannot be distinguished). In the basin center, the cleavage also kept forming during folding of the cover. As a result of the general west-verging shear due to the internal nappe overthrusting, the axial folds are eastdipping, as well as the cleavage (S1/S2), especially at high structural levels, while down in the basin the axial planes tend to remain sub-vertical. Near the basement cover interface, the eastverging folds, shear zones and cleavage are overprinted by west-verging shear zones, folds, and associated cleavage.

Figure 14: Balanced (a) and restored (b) cross section of the external Western Alps from the Valence basin to the Penninic Frontal Thrust. The Liassic layers that are detached just below the flysch and the FTP should, on the restored cross section, be much longer than represented and be extended further East. This has not been done, as their length cannot be precisely quantified.

Figure 15: Conceptual evolution and crustal rheology of the external Western Alps. The associated strength profiles have been calculated for the frictional Byerlee behaviour and a "weak" Byerlee behaviour (friction coefficient of 0.3). For the ductile parts of the crust, two curves are calculated for the dislocation creep laws with two different pre-exponential terms for basement (quartz) and for sediments (same law but with a pre-exponential terms 1000 times smaller) (see Le Pourhiet et al., 2004 for more details). a) Initial configuration of the crust. b) Oligocene phase. The deformation is relatively distributed and the crust is shortened 
thanks to thick shear zones. Locally below inherited basins, the underthrusted European crust is weaker than the inherited fault zone, because of the presence of weak sedimentary rocks. The normal faults are thus not reactivated. c) Present-day balanced cross section, i.e. after the formation of the Miocene fold-and-thrust belt.

\section{References}

Affolter, A., Faure, J.L., Gratier, J.P., Colletta, B. 2008. Kinematic models of deformation at the front of the Alps: new data from map-view restoration. Swiss J. Geosci. 101 (2008) 289303.

Barber, A.J. 1965. The history of the Moine Thrust Zone, Lochcarron and Lochalsh, Scotland. Proceedings of the Geolocal Association 76, 215-242.

Barbier, R., Barféty, J.C., Bordet, P., Fabre, J., Petiteville, J., Rivoirard, R., Vatin-Pérignon, N., Mouterde, R., Méloux, J. 1977. Carte géologique de la France (1/50 000), feuille Saint Jean de Maurienne (774), Bureau de Recherches géologiques et minières, Orléans.

Barbier, R., Barféty, J.C., Bocquet, A., Bordet, P., Le Fort, P., Meloux, J., Mouterde, R., Pêcher, A. \& Petiteville, M. 1973. Carte géologique de la France (1/50 000), feuille La Grave (798), Bureau de Recherches géologiques et minières, Orléans.

Barféty, J.C., Bordet, P., Carme, F., Debelmas, J., Meloux, M., Montjuvent, G., Mouterde, R. \& Sarrot-Reynauld, J. 1972: Carte géologique de la France (1/50000), feuille Vizille (797), Bureau de Recherches géologiques et minières, Orléans.

Barféty, J.C., Gidon, M., Lemoine, M., and Mouterde, R., 1979. Tectonique synsédimentaire liasique dans les massifs cristallins de la zone externe des Alpes occidentales françaises: la faille du col d'Ornon. Comptes Rendus de l'Académie des Sciences, 289, 1207-1210. 
Bayer, R., Carozzo, M.T., Lanza, R., Miletto, M., Rey, D. 1989. Gravity modelling along the ECORS-CROP vertical seismic reflection profile through the Western Alps. Tectonophysics $162,203-218$.

Beach, A. 1981. Thrust tectonics and cover-basement relations on the northern margin of the Pelvoux massif, French Alps. Eclogae geol. Helv. 74, 471-479.

Buiter, S.J.H., and Pfiffner, O.A. 2003. Numerical models of the inversion of half-graben basins. Tectonics 22, doi:10.1029/2002TC001417.

Burkhard, M., 1988. L'helvétique de la bordure occidentale du massif de l'Aar (Evolution tectonique et métamorphique). Eclogae Geologicae Helvetiae, 81, 63-114.

Burkhard, M., and Sommaruga, A., Evolution of the western Swiss Molasse basin: structural relations with the Alps and the Jura belt. In Cenozoic Foreland Basins of Western Europe. Geological Society Special Publications, 134. Mascle, A., Puigdefabregas, C., Luterbacher, H. P. \& Fernandez, M. (eds), 279-298.

Burov, E. B., and M. Diament, 1995. The effective elastic thickness (Te) of continental lithosphere: What does it really mean?, J. Geophys. Res. 100, 3905-3927.

Burov, E., and Yamato, P. 2008. Continental plate collision, $\mathrm{P}-\mathrm{T}-\mathrm{t}-\mathrm{Z}$ conditions and unstable vs. stable plate dynamics: Insights from thermo-mechanical modelling. Lithos 103, 178-204.

Butler, R.W.H. 1983. Balanced cross-sections and their implications for the deep structure of the northwest Alps. Journal of Structural Geology 5, 125-137.

Butler, R.W.H. 1989. The influence of pre-existing basin structure on thrust system evolution in the Western Alps. In Inversion Tectonics, Geological Society Special 44, Cooper, M. A. \& Williams, G. D. (eds), 105-122.

Butler, R.W.H., Tavarnelli, E., and Grasso, M., 2006. Structural inheritance in mountain belts: An Alpine-Apennine perspective. Journal of Structural Geology, 28, 1893-1908. 
Butler, R.W.H., Holdsworth, R.E., and Matthews, S.J. 2006b. Styles of basement involvment in the Moine Thrust Belt, NW Scotland. 2006. In Styles of Continental Contraction, Mazzoli, S., and Butler, R.W.H., (eds) Geological Society of America Special Papers 414, $133-151$

Butler, R.W.H., 2010, The role of thrust tectonic models in understanding structural evolution in NW Scotland. In: Law, R.D., Butler, R.W.H., Holdsworth, R.E., Krabbendau, M. and Strachan, R.A. (eds) Continental Tectonics and Mountain Building: The Legacy of Peach and Horne. Geological Society, London, Special Publications 335, 293-320, doi: $10.1144 / \mathrm{SP} 335.14$

Challandes, N., Marquer, D., Villa, I.M., 2008. P-T-t modelling, fluid circulation, and 39Ar40Ar and Rb-Sr mica ages in the Aar Massif shear zones (Swiss Alps). Swiss Journal of Geosciences 101, 269-288

Choukroune, P., and Gapais, D., 1983. Strain pattern in the Aar Granite (Central Alps): Orthogneiss developed by bulk inhomogeneous flattening. Journal of Structural Geology, 5, 411-418.

Colletta, B., Le Quellec, P., Letouzey, J., Moretti, I. 1984. Longitudinal evolution of the Suez rift structure (Egypt). Tectonophysics 153, 221-233.

Cristallini, E.O., and Ramos, V.A. 2000. Thick-skinned and thin-skinned thrusting in the La Ramada fold and thrust belt: crustal evolution of the High Andes of San Juan, Argentina $\left(32^{\circ} \mathrm{SL}\right)$. Tectonophysics $317,205-235$.

Crouzet, C., Menard, G., and Rochette, P., 2001. Cooling history of the Dauphinoise Zone (Western Alps, France) deduced from the thermopaleomagnetic record: geodynamic implications. Tectonophysics, 340, 79-93. 
de Graciansky, P.C., Dardeau, G., Lemoine, M., and Tricart, P., 1989, The inverted margin of the French Alps and foreland basin inversion, Geological Society of London Special Publications 44, p. 87-104.

Debelmas, J., Gidon, M., Bellière, J., von Raumer, J., Rosset, J., Charollais, J., Barféty, J.C., Lemoine, M., Caron, J.M., Ellenberger, F., Caby, R., Elter, P., Dal Piaz, G.B., Nicolas, A., Monjuvent, G., Carraro, F. 1980: Carte géologique de la France (1/250000), feuille Annecy (30), Bureau de Recherches géologiques et minières, Orléans.

Deville, E., Mascle, A., Lamiraux, C., Le Bras, A. 1994. Tectonic styles, reevaluation of splays in southeastern France. Oil and Gas Journal, 53-58

Deville, E., and Chauvière, A., 2000. Thrust tectonics at the front of the western Alps: constraints provided by the processing of seismic reflection data along the Chambery transect. Comptes Rendus de l'Académie des Sciences, 331, 725-732.

Dumont, T., Champagnac, J.D., Crouzet, C., and Rochat, P., 2008. Multistage shortening in the Dauphiné zone (French Alps): the record of Alpine collision and implications for preAlpine restoration. Swiss Journal of Geosciences, doi 10.1007/s00015-008-1280-2.

Dumont, T., Simon-Labric, T., Authemayou, C., and Heymes, T. 2011. Lateral termination of the north-directed Alpine orogeny and onset of westward escape in the Western Alpine arc: Structural and sedimentary evidence from the external zone. Tectonics 30, doi:10.1029/2010TC002836.

Dumont, T., Schwartz, S., Guillot, S., Simon-Labric, T., Tricart, P., Jourdan, S. Structural and sedimentary records of the Oligocene revolution in the Western Alpine arc. Journal of Geodynamics, in press.

Escher, A., Masson, H., Steck, A. 1993. Nappe geometry in the western Swiss Alps, Journal of Structural Geology 15, $501-509$. 
Epard, J.L. 1986. Le contact entre le socle du Mont-Blanc et la zone de Chamonix: Implications tectoniques, Bull. Soc. Vaudoise Sci. Nat. 78, 225 - 245.

Faccenda M., Minelli G., and Gerya, T.V. 2009. Coupled and decoupled regimes of continental collision: Numerical modelling. Earth and Planetary Science Letters 278, 337349.

Ford, M., 1996. Kinematics and geometry of early Alpine, basement involved folds, SW Pelvoux Massif, SE France. Eclogae Geologicae Helvetiae, 89, 269-295.

Ford, M., Duchêne, S., Gasquet D., Vanderhaeghe, O. 2006. Two-phase orogenic convergence in the external and internal SW Alps. Journal of the Geological Society 163, $815-826$

Gidon, M., 1979. Le rôle des étapes successives de déformation dans la tectonique alpine du Massif du Pelvoux (Alpes occidentales). Comptes Rendus de l'Academie des Sciences, 288, 803-806.

Gidon, M., 1999. L'origine des abrupts septentrionaux du Taillefer, massifs cristallins externes, Isère, France. Géologie Alpine, 75, 103-109.

Gidon, M., 2001. Les massifs cristallins externes des Alpes occidentales françaises sont-ils charriés? Géologie Alpine 77, 23-38.

Gillcrist, R., Coward, M., and Mugnier, J.L., 1987. Structural inversion and its controls: examples from the Alpine foreland and the French Alps. Geodinamica Acta, 1, 5-34.

Gourlay, P., 1986. The alpine deformation of the basement and the cover in the mont-blanc area (western alps). Bulletin de la Société Géologique de France 2, p. 159-169.

Gratier, J.-P., and Vialon, P., 1980. Deformation pattern in a heterogeneous material: Folded and cleaved sedimentary cover immediately overlying a crystalline basement (Oisans, French Alps). Tectonophysics, 65, 151-179. 
Jackson, J.A. 1980. Reactivation of basement faults and crustal shortening in orogenic belts, Nature 283, 343-346.

Jullien, M., and Goffé, B., 1993. Occurrences de cookéite et de pyrophylitte dans les schistes du Dauphinois (Isère, France): conséquences sur la répartition du métamorphisme dans les zones externes alpines. Schweizerische Mienralogische und Petrographische Mitteilungen, $73,357-363$

Kaus, B.J.P., Steedman, C., and Becker, T.W. 2008. From passive continental margin to mountain belt: Insights from analytical and numerical models and application to Taiwan. Physics of the Earth and Planetary Interiors 171, 235-251.

Kerckhove, C., Gidon, M., Malaroda, R., Barféty, J.C., Bogdanoff, S., Lemoine, Carraro, F., Jorda, M., Monjuvent, G., 1980: Carte géologique de la France (1/250000), feuille Gap (35), Bureau de Recherches géologiques et minières, Orléans.

Lacombe, O., and Mouthereau, F., 2002. Basement-involved shortening and deep detachment tectonics in forelands of orogens: Insights from recent collision belts (Taiwan, Western Alps, Pyrenees). Tectonics, 21, 4, 1030, 10.1029/2001TC901018.

Lardeaux, J.M., Schwartz, S., Tricart, P., Paul, A., Guillot, S., Béthoux, N., Masson, F. A crustal-scale cross-section of the south-western Alps combining geophysical and geological imagery. Terra Nova 18, 412-422.

Leloup, P.H., Arnaud, N., Sobel, E.R., and Lacassin, R., 2005. Alpine thermal and structural evolution of the highest external crystalline massif: The Mont Blanc. Tectonics, 24, TC4002, doi:10.1029/2004TC001676.

Lemoine, M., Bas, T., Arnaud-Vanneau, A., Arnaud, H., Dumont, T., Gidon, M., Bourbon, M., de Graciansky, P.-C., Rudkiewicz, J.-L., Megard-Galli, J., and Tricart, P., 1986. The continental margin of the Mesozoic Tethys in the Western Alps. Marine and Petroleum Geology, 3, 179-199. 
Lemoine, M., Gidon, M., and Barféty, J.C., 1981. Les Massifs Cristallins Externes des Alpes occidentales: d'anciens blocs basculés nés au Lias, lors du rifting téthysien. Comptes Rendus de l'Académie des Sciences, 292, 917-920.

Le Pourhiet, L., Burov, E., and Moretti, I. 2004. Rifting through a stack of inhomogeneous thrusts (the dipping pie concept). Tectonics 23, doi:10.1029/2003TC001584.

Letouzey, J., 1990, Fault reactivation, inversion and foldthrust belt. in Petroleum and Tectonics in Mobile Belts, edited by J. Letouzey, Technip, Paris, 101-128.

Malavieille, J., Lacassin, R., and Mattauer, M., 1984. Signification tectonique des linéations d'allongement dans les Alpes occidentales. Bulletin de la Société Géologique de France, 5, $895-906$.

Marquer, D., 1990. Structure et déformation alpine dans les granites hercyniens du massif du Gothard (Alpes centrales Suisses). Eclogae Geologicae Helvetiae 83, 77-97.

Marquer, D., Calcagno, P., Barfety, J.-C., and Baudin, T., 2006. 3D modelling and kinematics of the external zone of the french western Alps (Belledonne and Grand Châtelard Massifs, Maurienne Valley, Savoie). Eclogae Geologicae Helvetiae, doi 10.1007/s00015-006-1183-z.

Marshak, S., Karlstrom, K., Timmons, J.M. 2000. Inversion of Proterozoic extensional faults: An explanation for the pattern of Laramide and Ancestral Rockies intracratonic deformation, United States. Geology 28, 735-738.

Masson, F., Verdun, J., Bayer, R., Debeglia, N. 1999. Une nouvelle carte gravimétrique des Alpes occidentales et ses consequences structurales et tectoniques, C. R. Acad. Sci. Paris $329,865-871$.

Masson, F., Gala, F., Leloup, P.H. 2002. Une carte gravimétrique haute résolution du massif du Mont-Blanc : implications structurales. Comptes Rendus Geoscience 334, 1011-1019.

Menard, G. 1979. Relations entre structures profondes et structures superficielles dans le SudEst de la France, essai d'utilisation de données géophysiques. Ph.D. thesis, Grenoble. 179 p. 
Menard, G., and Thouvenot, F., 1987. Balanced cross-sections at crustal scale: methods and application to the western Alps. Geodinamica Acta 1, 35-45

Michard, A., Dumont, T., Andreani L., and Loget, N., 2010, Cretaceous folding in the Dévoluy mountains (Subalpine Chains, France): gravity-driven detachment at the European paleomargin versus compressional event, Bulletin de la Société Géologique de France 181, p 565-581, DOI:10.2113/gssgfbull.181.6.565

Mosar, J., 1999. Present-day and future tectonic underplating in the western Swiss Alps: reconciliation of basement/wrench-faulting and décollement folding of the Jura and Molasse basin in the Alpine foreland. Earth and Planetary Science Letters 173,143-155.

Mouthereau, F. and Lacombe, O. 2006. Inversion of the Paleogene Chinese continental margin and thick-skinned deformation in the Western Foreland of Taiwan. Journal of Structural Geology 28, 1977-1993.

Mouthereau, F. and Petit, C. 2003. Rheology and strength of the Eurasian continental lithosphere in the foreland of the Taiwan collision belt: Constraints from seismicity, flexure, and structural styles. Journal of Geophysical Research 108, doi:10.1029/2002JB002098, 2003.

Mugnier, J.L., Guellec, S., Menard, G., Roure, F., Tardy, M., Vialon, P. 1990. A crustal scale balanced cross-section through the external Alps deduced from the ECORS profile. Mém. Soc. Géol. Fr. 156, 203-216.

Nicolas, A., Hirn, A., Nicolich, R. Polino, R. and the ECORS-CROP Working Group. 1990. Lithospheric wedging in the western Alps inferred from the ECORS-CROP program. Geology 18, 587-590

Oliot, E., Goncalves, P., and Marquer, D. 2010. Role of plagioclase and reaction softening in a metagranite shear zone at mid-crustal conditions (Gotthard Massif, Swiss Central Alps). Journal of Metamorphic Geology 28, 849-871 doi:10.1111/j.1525-1314.2010.00897.x 
Pfiffner, O. A., Lehner, P., Heitzmann, P., Müller, S., Steck, A. 1997. Deep Structure of the Swiss Alps: Results of NRP 20, Springer, New York.

Phillippe, Y., Deville, E. \& Mascle, A. 1998. Thin-skinned inversion tectonics at oblique basin margins: example of the western Vercors and Chartreuse Subalpine massifs (SE France). In: Mascle, A., Puigdefabregas, C., Luterbacher, H. P. \& Fernandez, M. (eds) Cenozoic Foreland Basins of Western Europe. Geological Society Special Publications 134, 239-262.

Ramsay, J. G. 1981, Tectonics of the Helvetic nappes, in Thrust and Nappe Tectonics, Spec. Publ. Geol. Soc. 9. K. R. McClay and N. J. Price (Eds), 293-309.

Ranalli, G. 1995. Rheology of the Earth. Springer. 436 p.

Rolland, Y., Cox, S.F., Boullier, A.M., Pennacchioni, G., Mancktelow, N., 2003. Rare Earth and trace element mobility and fractionation in mid-crustal shear zones: insights from the Mont-Blanc Massif (Western Alps). Earth and Planetary Science Letters 214, 203-219.

Rolland, Y., Corsini, M., Rossi, M., Cox, S.F., Pennacchioni, G., Mancktelow, N., Boullier, A.M., 2007. Comment on "Alpine thermal and structural evolution of the highest external crystalline massif: The Mont Blanc' by P.H. Leloup, N. Arnaud, E.R. Sobel, and R. Lacassin. Tectonics 26, TC2015. doi:10.1029/2006TC001956.

Rolland, Y., Rossi, M., Cox, S.F., Corsini, M., Boullier, A.M., Pennachioni, G., Mancktelow, N., 2008. 40Ar/39Ar dating of syn-kinematic white mica: insights for fluid-rock reaction in low-grade shear zones (Mont Blanc Massif) and constraints on timing of deformation in the NW external Alps. In: Wibberley, C., Kurtz, W., Imber, J., Holdsworth, R.E., Collettini, C. (Eds.), The Internal Structure of Fault Zones: Implications for Mechanical and Fluid-Flow Properties. Geological Society of London, Special Publications, pp. 293-315. doi:10.1144/ SP299.17. 
Rolland, Y., Cox, S.F., Corsini, M. Constraining deformation stages in brittle-ductile shear zones from combined field mapping and 40Ar/39Ar dating: The structural evolution of the Grimsel Pass area (Aar Massif, Swiss Alps). Journal of Structural Geology 31, 1377-1394

Roure, F., Heitzmann, P. \& Polino, R. (Eds.) 1990. Deep structure of the Alps. Mémoire de la Société géologique de France 156, 345 pp.

Roure, F., and Colletta., B. 1996. Cenozoic inversion structures in the foreland of the Pyrenees and Alps. In Ziegler, P.A., and Horvath, F., (Eds), Peri-Tethys Memoir 2: Structure and Prospects of Alpine and Forelands. Mém. Mus. Natn. Hist. nat. 170, 173-209.

Sanchez, G., Rolland, Y., Jolivet, M., Brichau, S., Corsini, M., Carter, A. 2011. Exhumation controlled by transcurrent tectonics: the Argentera-Mercantour massif (SW Alps). Terra Nova 23, doi:10.1111/j.1365-3121.2011.00991.x

Saura, E., and Teixell, A. 2006. Inversion of small basins: effects on structural variations at the leading edge of the Axial Zone antiformal stack (Southern Pyrenees, Spain). Journal of Structural Geology 28, 1909-1920.

Schmid S.M., Fügenschuh, B., Kissling, E., Schuster, R. 2004. Tectonic map and overall architecture of the Alpine orogen. Eclogae geol. Helv. 97, 93-117.

Sibson, R.H. 1995. Selective fault reactivation during basin inversion: potential for fluid redistribution through fault-valve action. In Basin Inversion, Buchanan, J. G. \& Buchanan, P. G. (eds), Geological Society Special Publication 88, 3-19.

Simon-Labric, T., Rolland, Y., Dumont, T., Heymes, T., Authemayou, C., Corsini, M., and Fornari, M., 2009. 40Ar/39Ar dating of Penninic Front tectonic displacement (W Alps) during the Lower Oligocene (31-34 Ma). Terra Nova, doi: 10.1111/j.13653121.2009.00865.x.

Sinclair, H.D. 1997. Tectonostratigraphic model for underfilled peripheral foreland basins : An Alpine perspective. GSA Bulletin 109, 324-346. 
Sue, C., Tricart, P., Dumont, T., and Pecher, A., 1997. Raccourcissement polyphase dans le massif du Pelvoux (Alpes occidentales): exemple du chevauchement de socle de VillardNotre-Dame. Comptes Rendus de l'Academie des Sciences - Series IIA - Earth and Planetary Science, 324, 847-854.

Thouvenot, F., Paul, A., Frechet, J., Bethoux, N., Jenatton, L., Guiguet, R. 2007. Are there really superposed Mohos in the southwestern Alps? Newseismic data from fan-profiling reflections. Geophysical Journal International 170, 1180-1194, doi: 10.1111/j.1365246X.2007.03463.x

Tricart, P., and Lemoine, M., 1986. From faulted blocks to megamullions and megaboudins: Tethyan heritage in the structure of the Western Alps. Tectonics, 5, 95-118.

Trift, M., and de Graciansky, P.C. 1988. Aspects of the tethyan rifting - small-scale grabens and mega-breccias of late liassic age on top of the emparis plateau (isere and hautes-alpes, france). Bulletin de la Société Géologique de France 4, 643-650

Van Baelen, H. \& Sintubin, M. 2008. Kinematic consequences of an angular unconformity in simple shear: an example from the southern border of the Lower Palaeozoic Rocroi inlier (Naux, France). Bulletin de la Société Géologique de France 179, 73-87.

van der Beek, P.A., Vall, P.G., Herman, F., Braun, J., Persano, C., Dobson, K.J., Labrin, E. 2010. Inversion of thermochronological age-elevation profiles to extract independent estimates of denudation and relief history - II: Application to the French Western Alps. Earth and Planetary Science Letters 296, 9-22.

Vernon, A.J., vanderBeek, P., Sinclair, H.D., and Rahn, M.K., 2008. Increase in late Neogene denudation of the European Alps confirmed by analysis of a fission-track thermochronology database. Earth and Planetary Science Letters, 270, 316-329.

Vialon, P. 1968. Clivages schisteux et déformations: répartition et genèse dans le bassin mésozoïque de Bourg-d'Oisans (Alpes du Dauphiné). Géologie Alpine 44, 353-366. 
Watts, A. B., S. H. Lamb, J. D. Fairhead, and J. F. Dewey, Lithospheric flexure and bending of the central Andes, Earth Planet. Sci. Lett., 134, 9-21, 1995.

Wibberley, C., 1999. Are feldspar-to-mica reactions necessarily reaction-softening processes in fault zones? Journal of Structural Geology, 21, 1219-1227.

Wibberley, C., 2005, Initiation of basement thrust detachments by fault-zone reaction weakening. In: Bruhn, D. and Burlini, L. (eds) High Strain Zones: Structures and Physical Properties. Geological Society, London, Special Publications, 245, 347-372.

Yamato, P., Mouthereau, F., and Burov, E. 2009. Taiwan mountain building: insights from 2D thermomechanical modelling of a rheologically stratified lithosphere. Geophys. J. Int. $176,307-326$. 


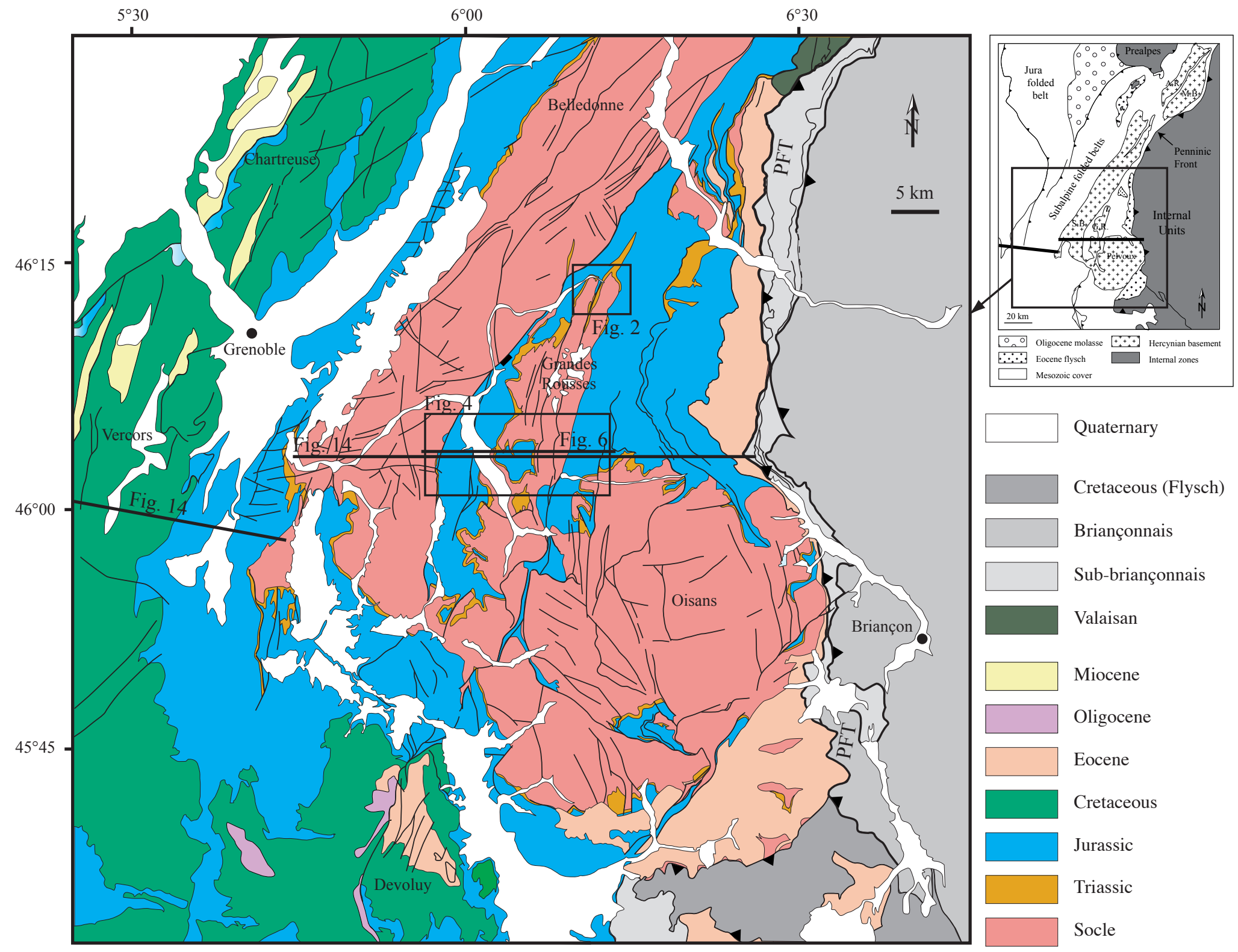

Figure 1 

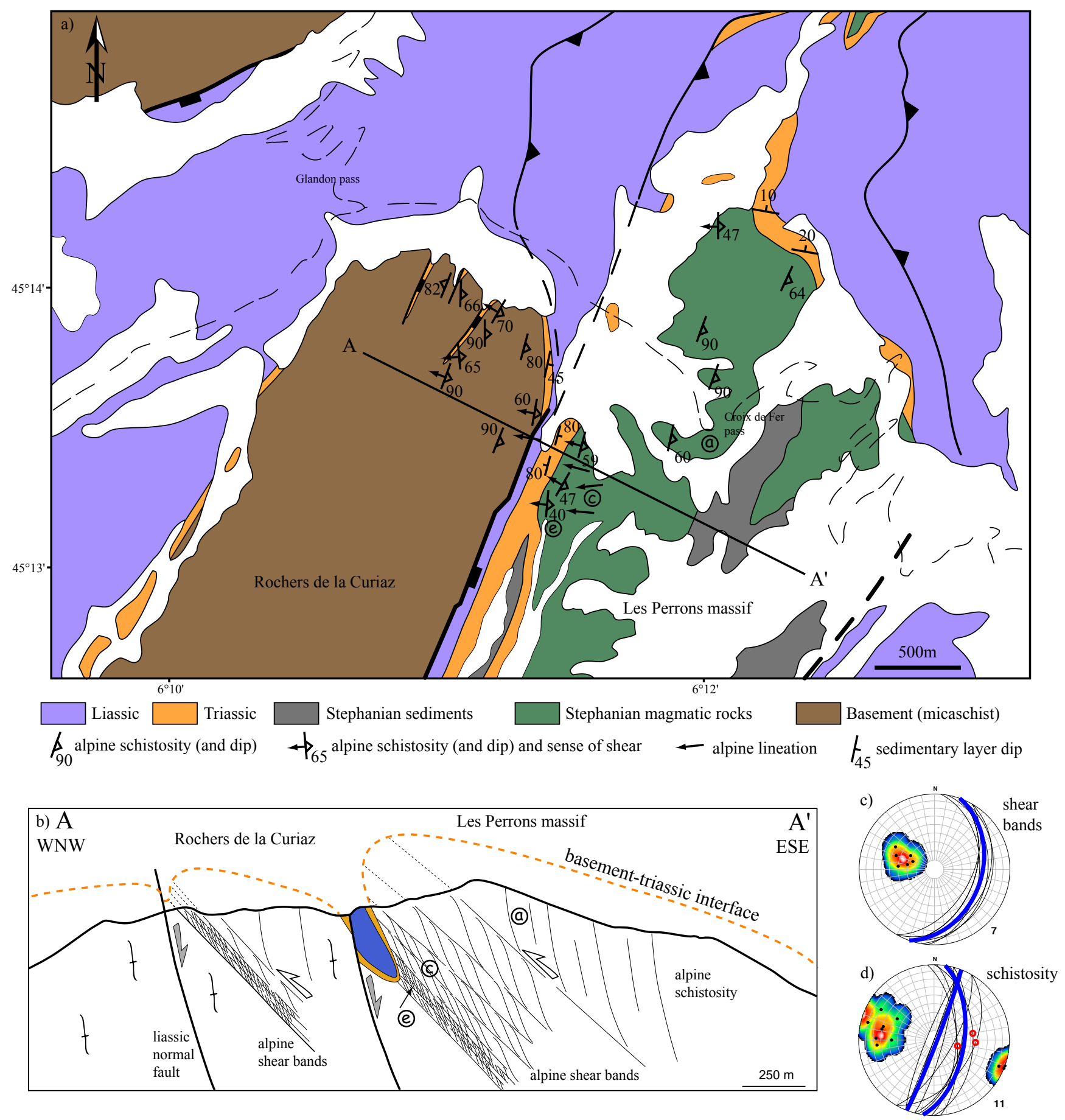

Figure 2 

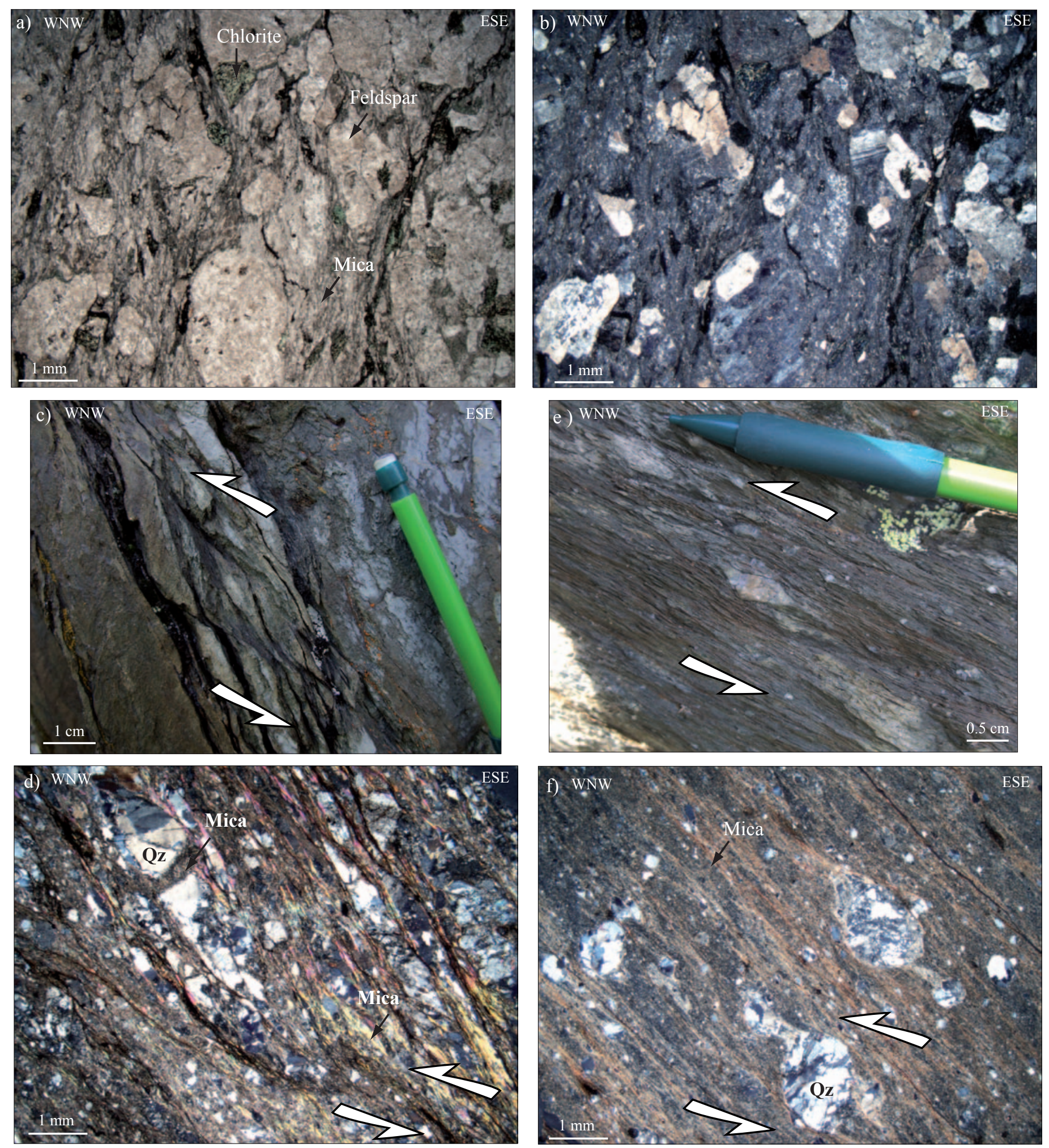

Figure 3 
a)

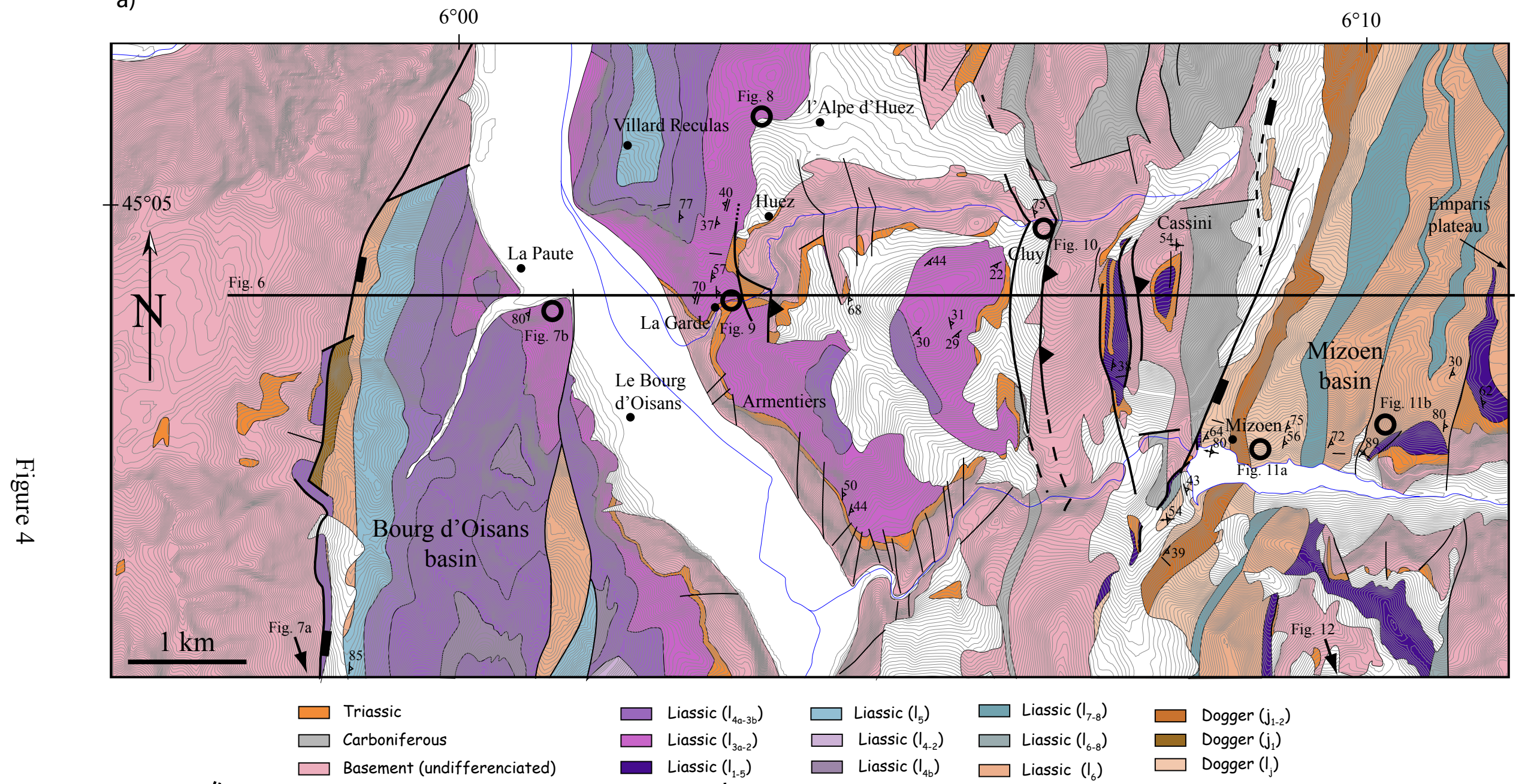

$\mathbb{P}_{40} \&_{90}$ Alpine schistosity/cleavage (and dip), S1 and S2 $\bigoplus_{65}$ Alpine schistosity/cleavage (and dip) and sense of shear — Alpine lineation

b) cleavage in Liassic strata

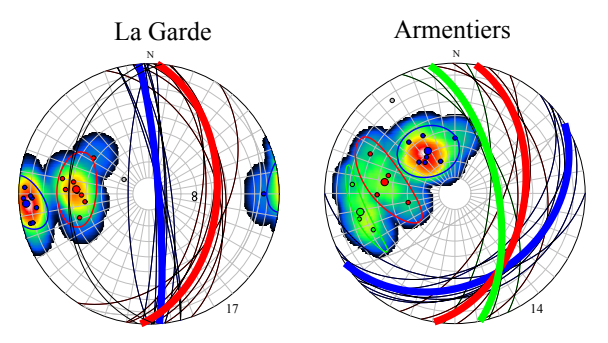

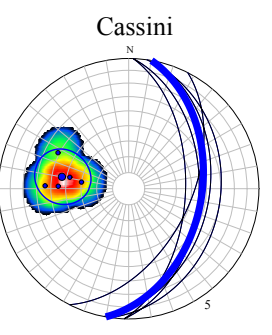

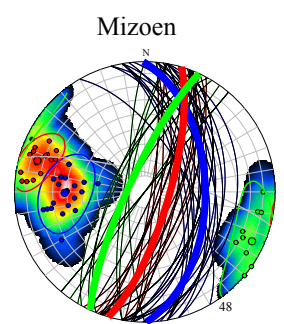

c) basement shear bands

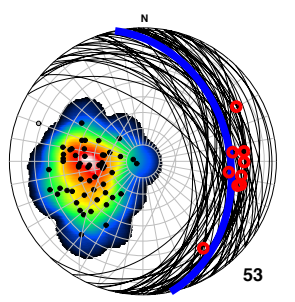

d) basement schistosity

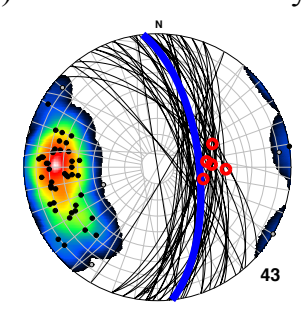



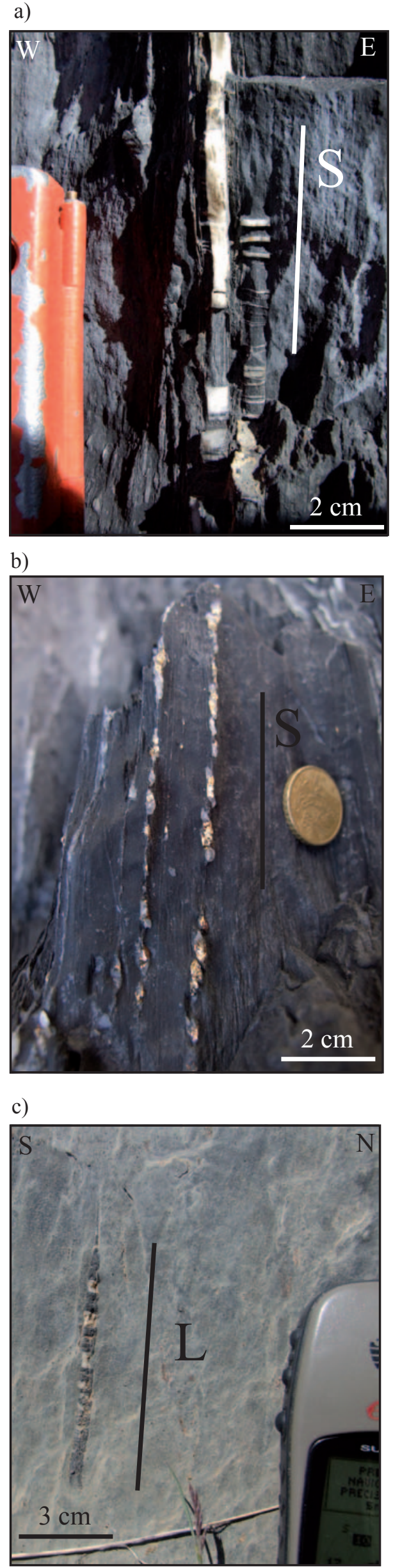

Figure 5 


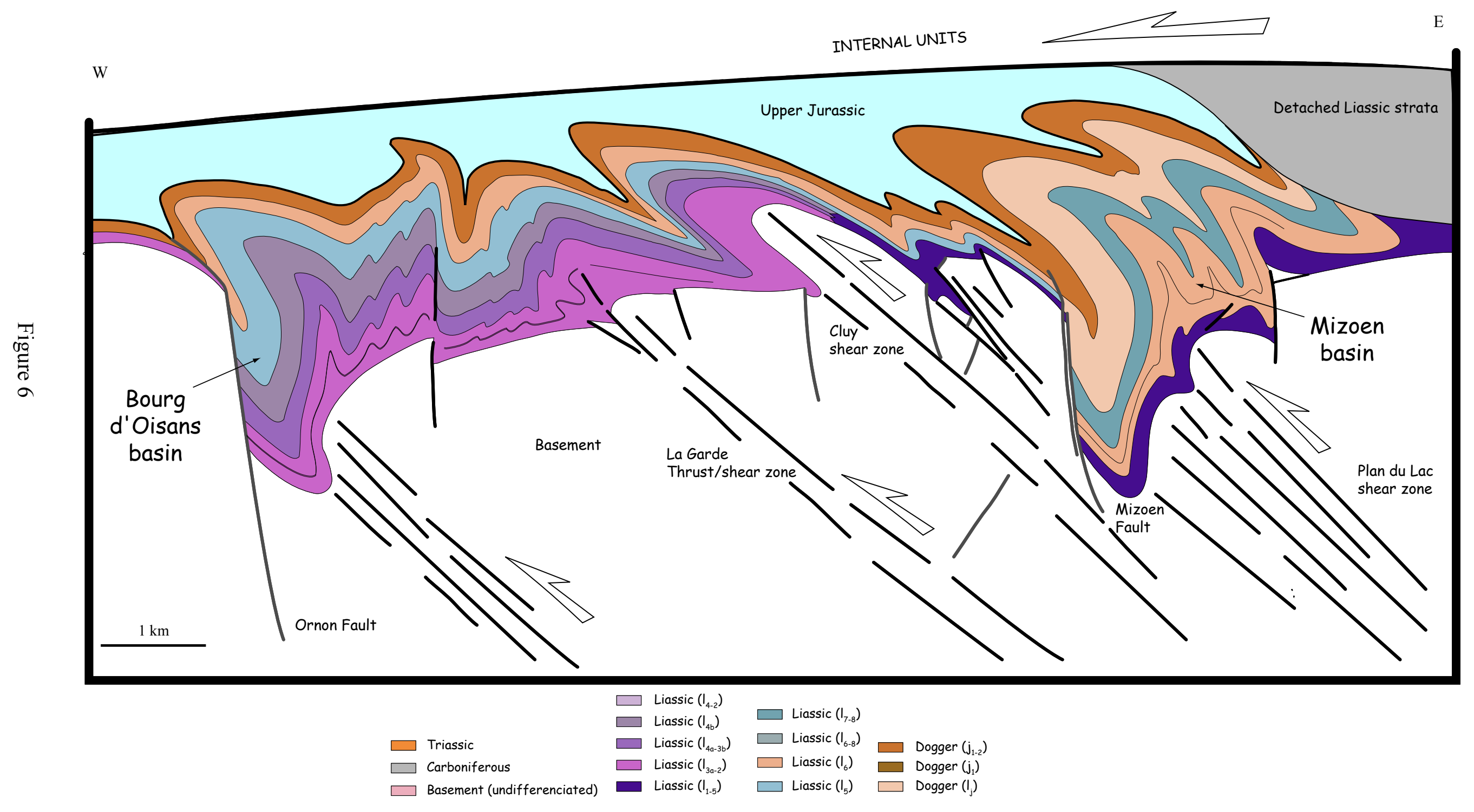


a)

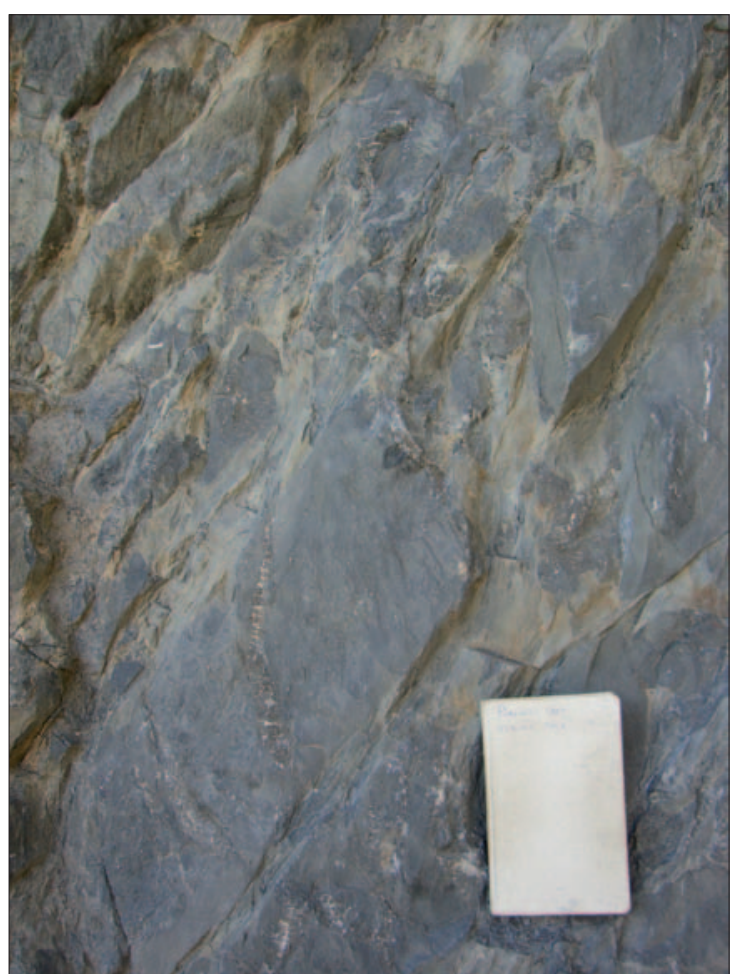

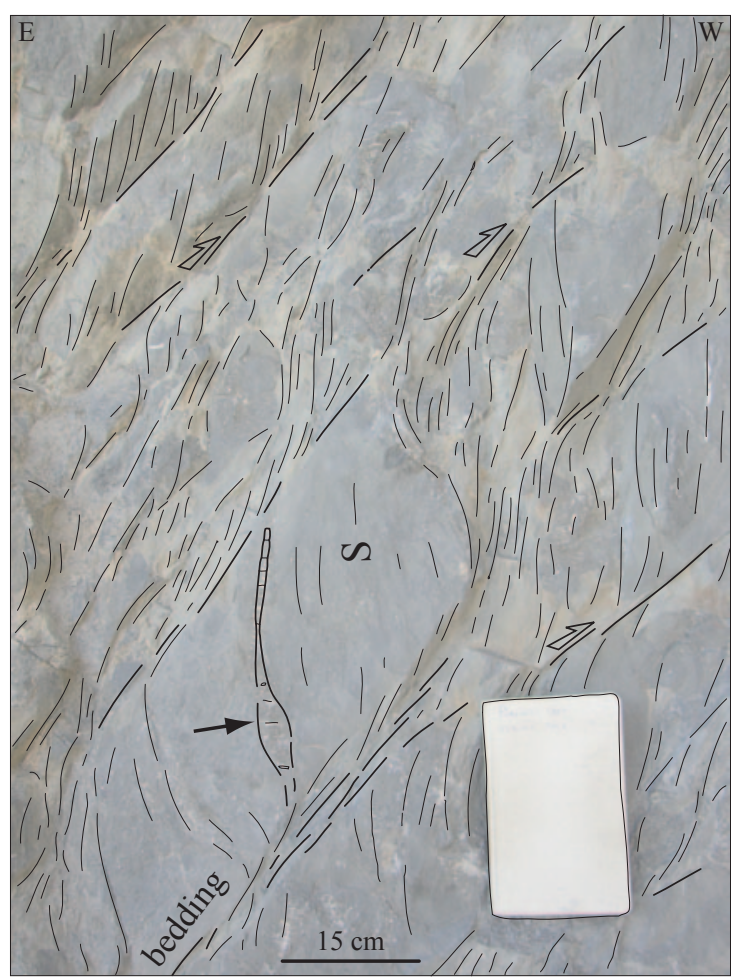

b)
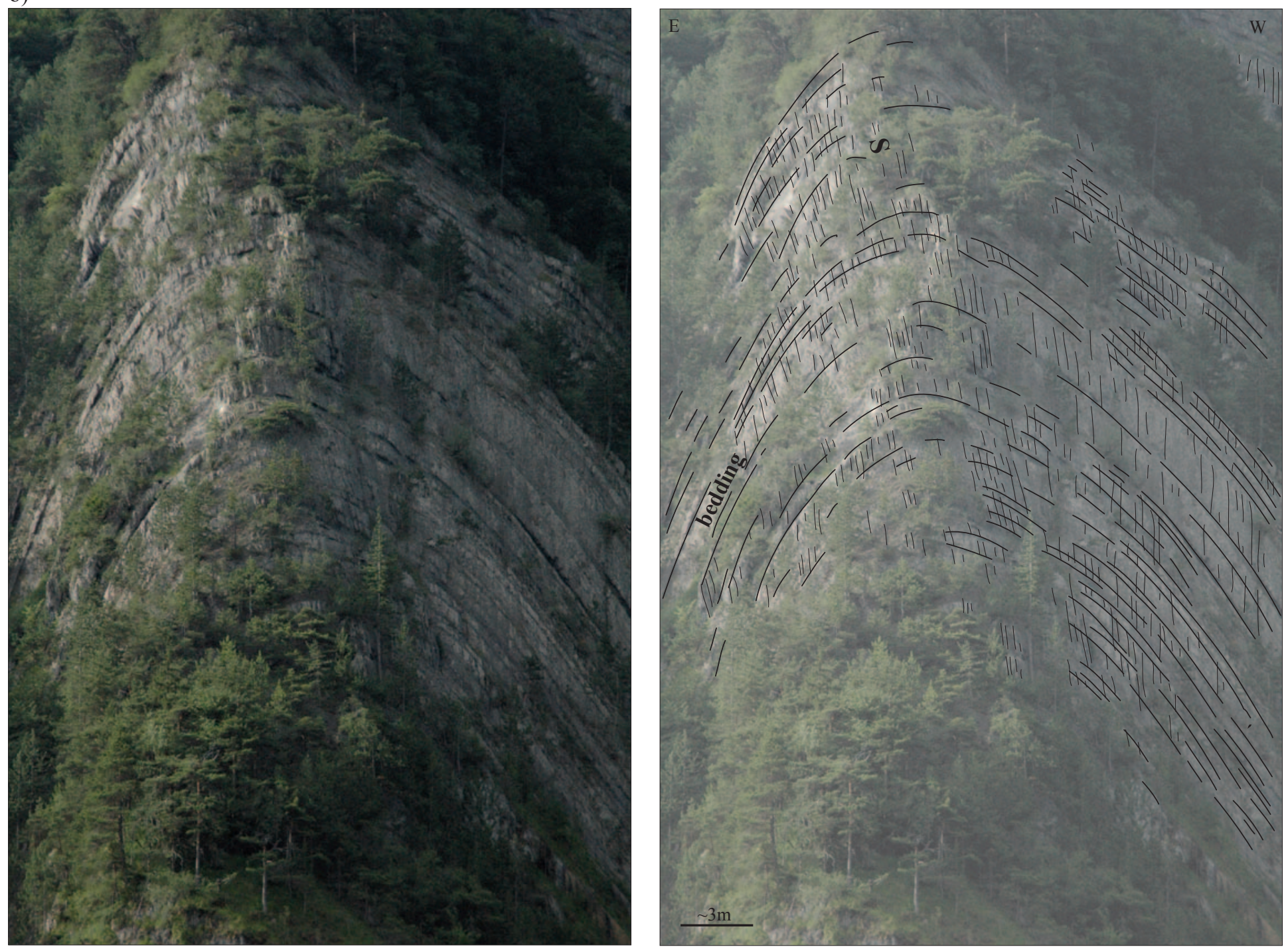

Figure 7 


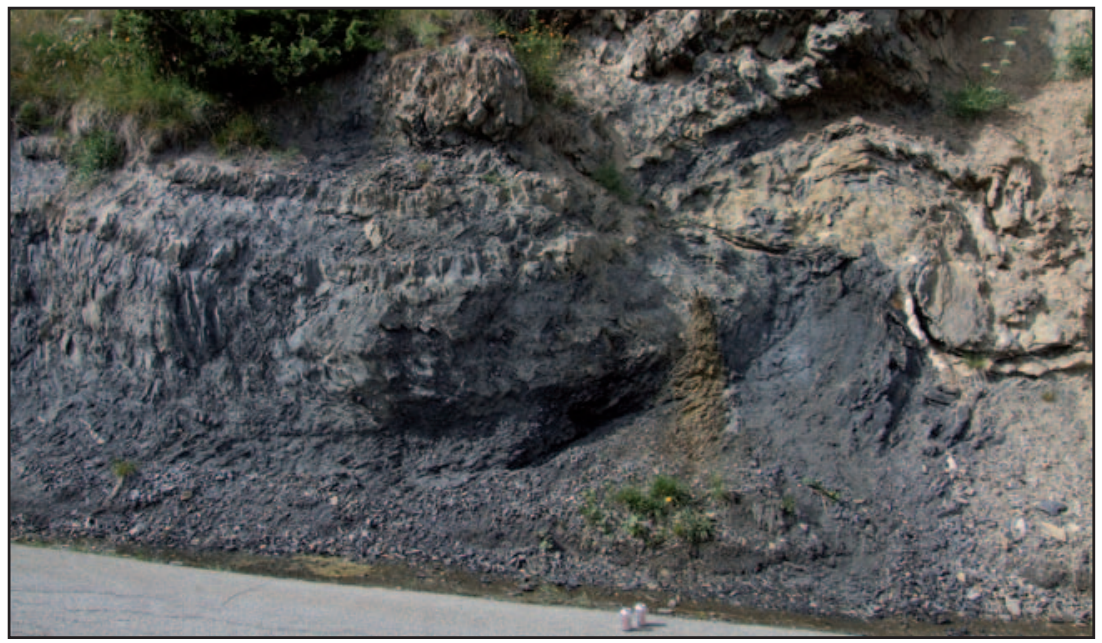

b)
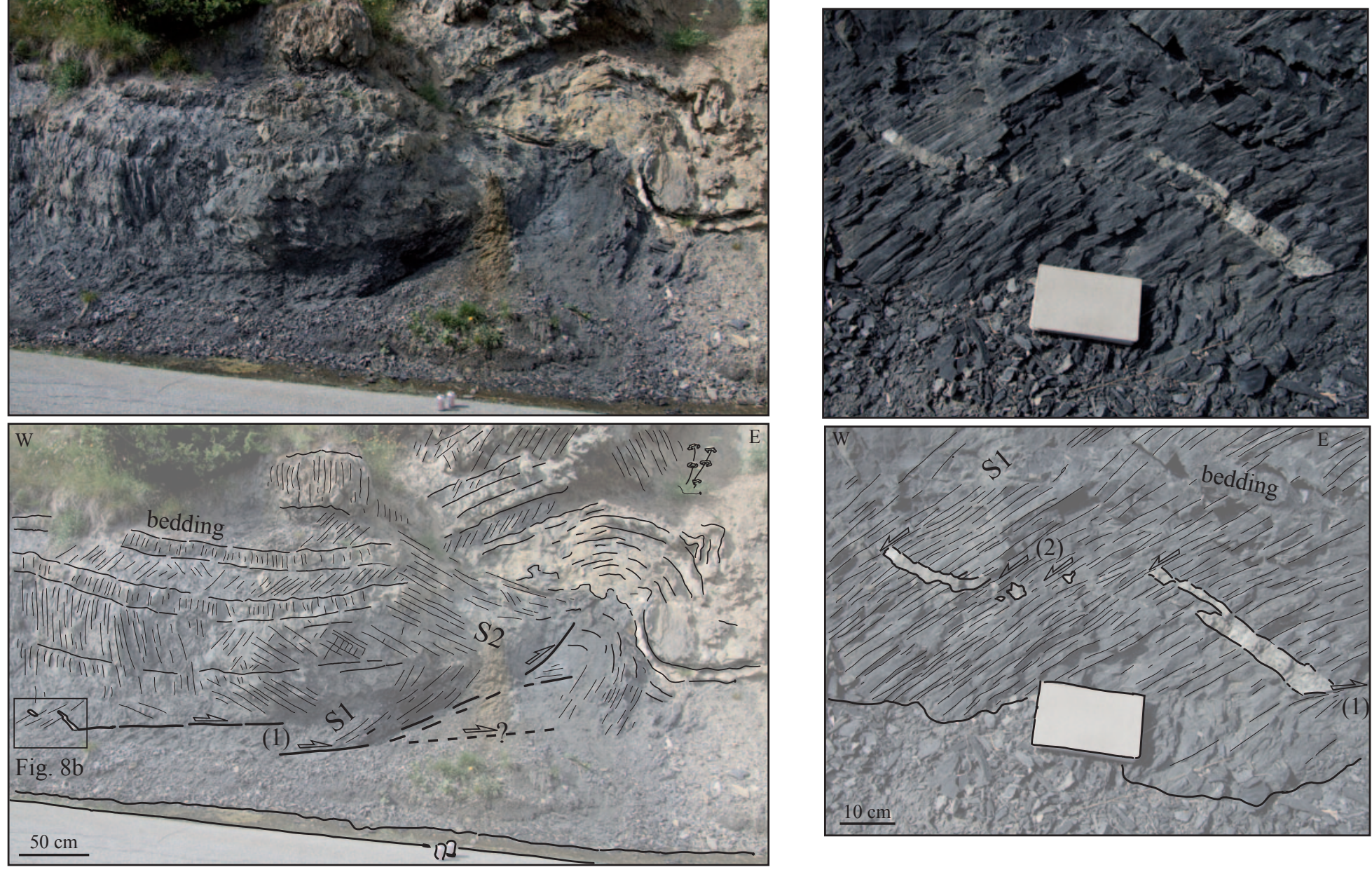

c)
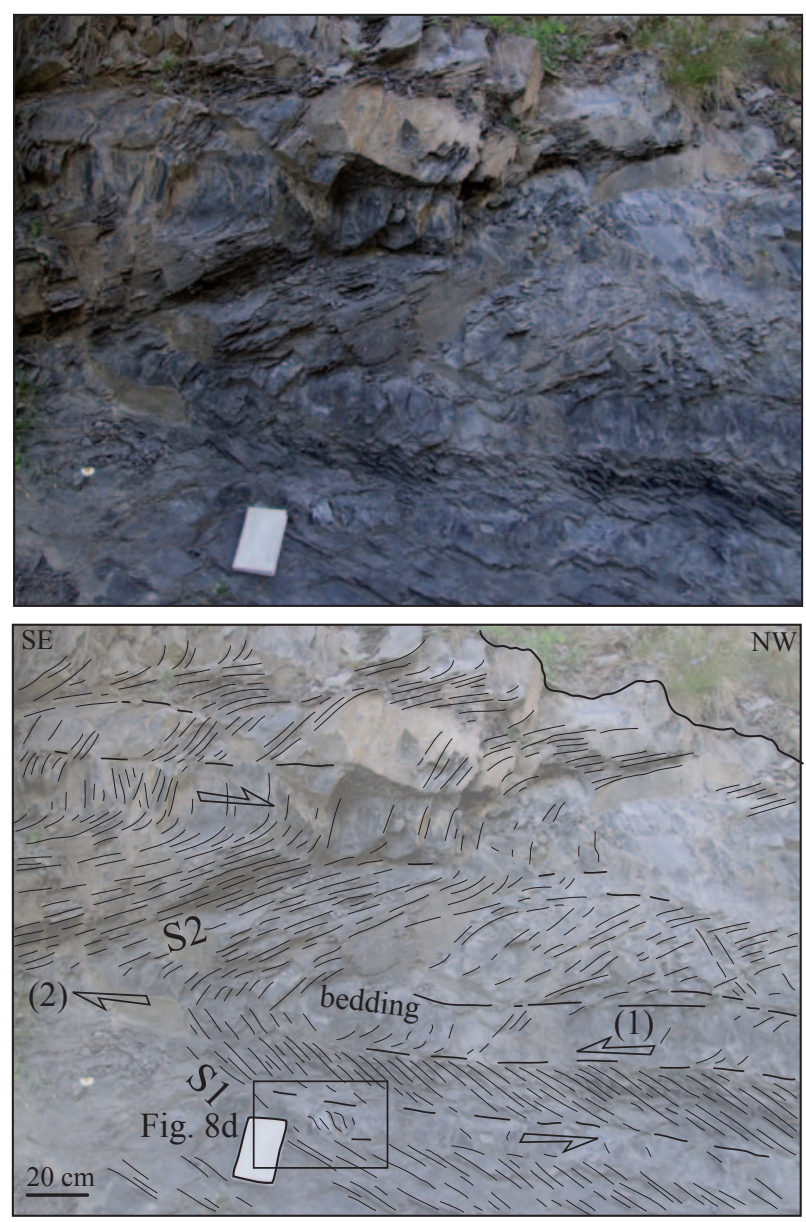

d)
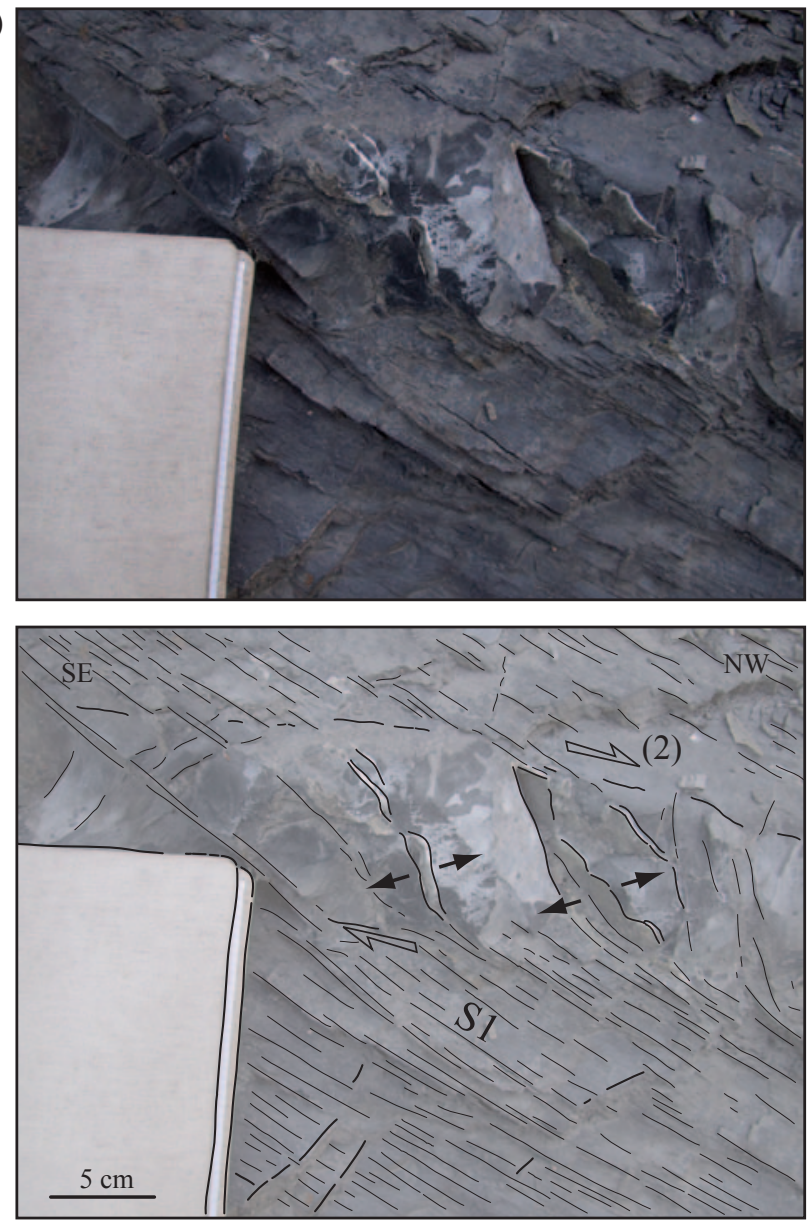

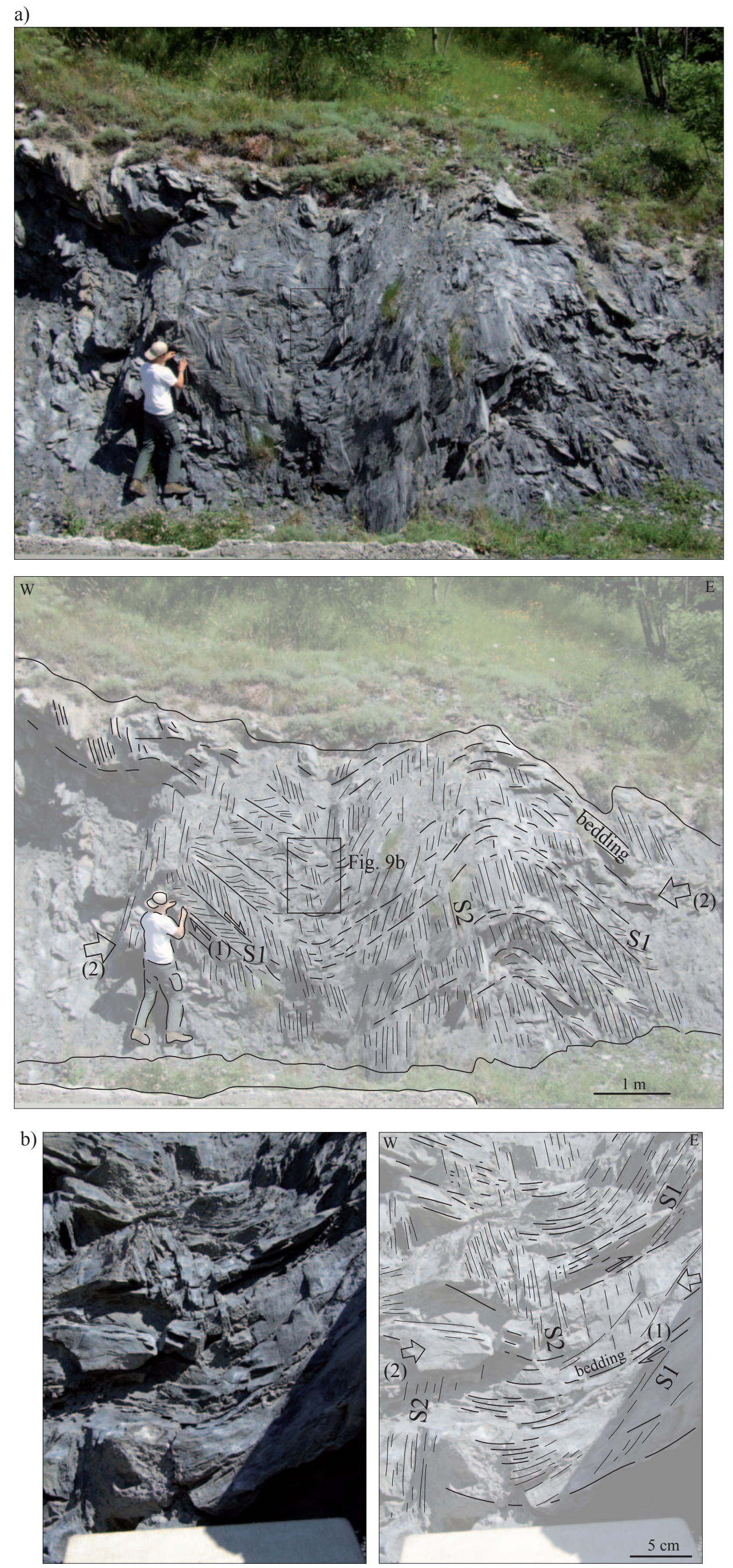


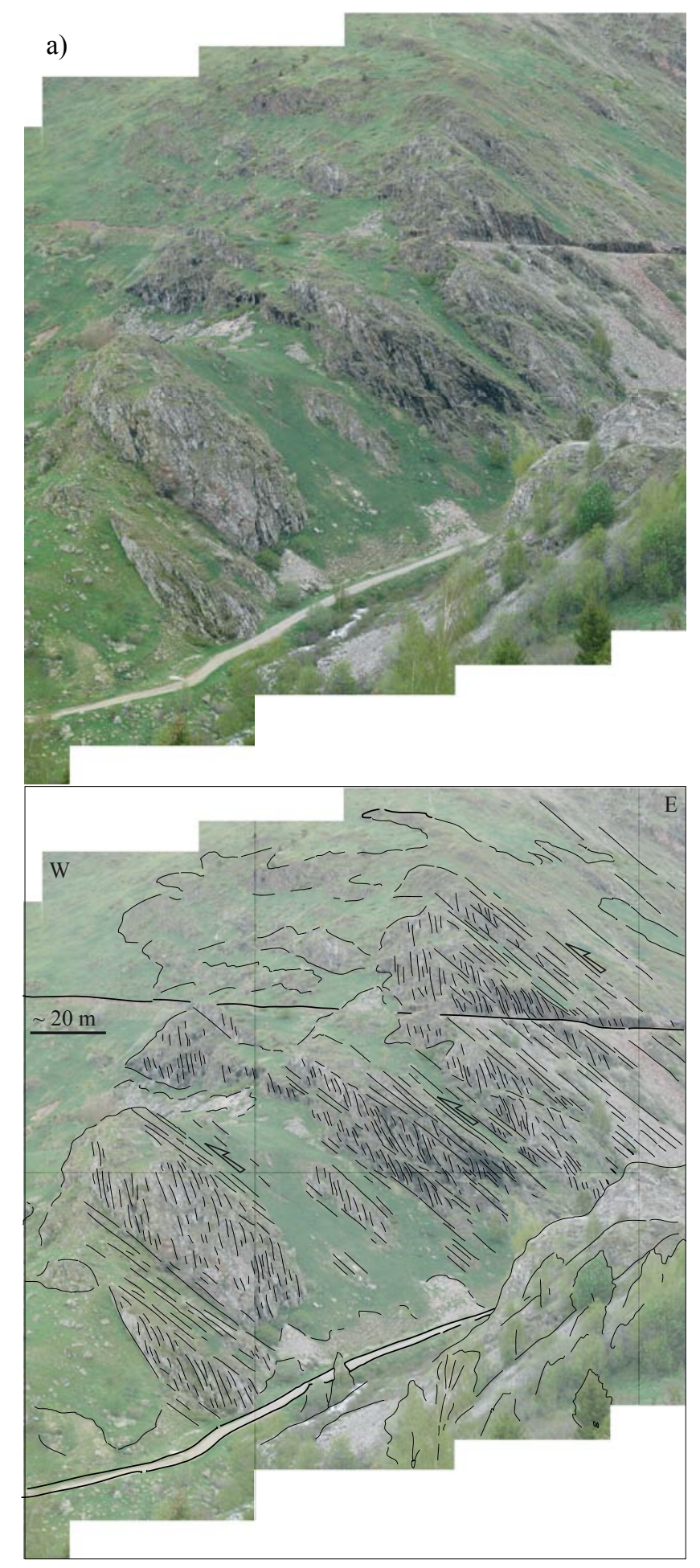

b)
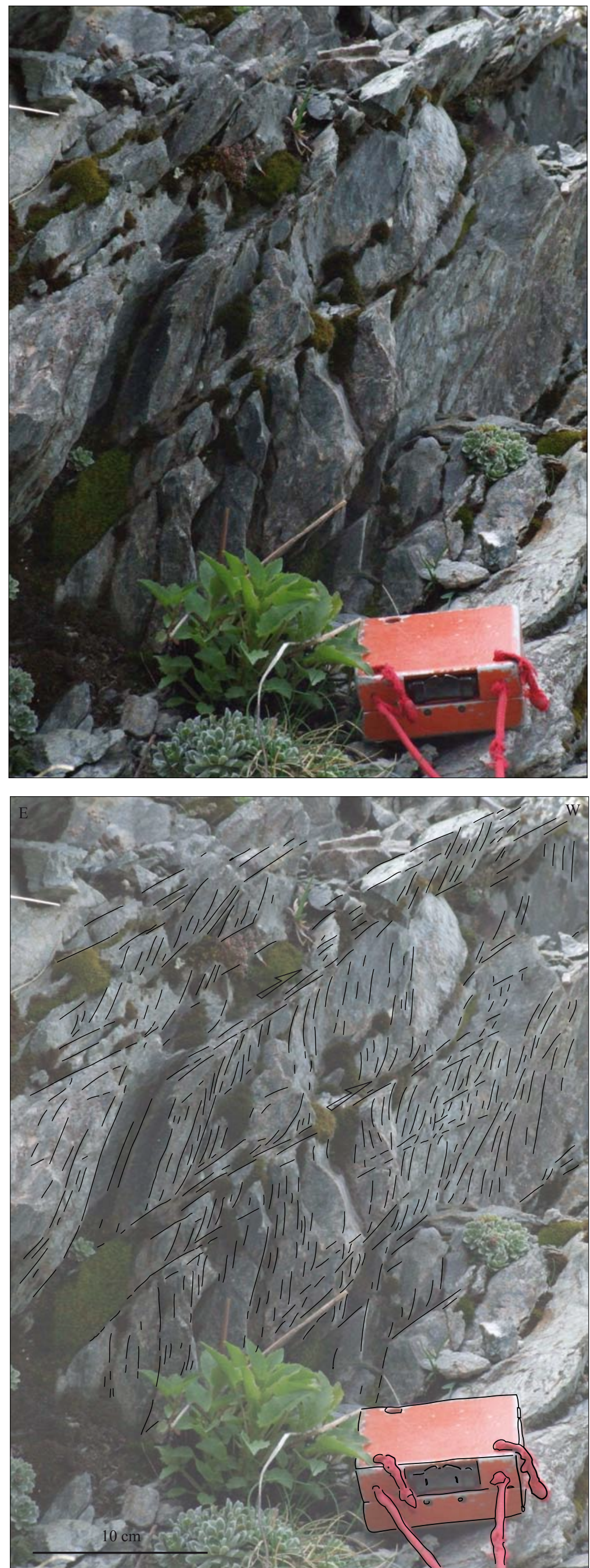

Figure 10 

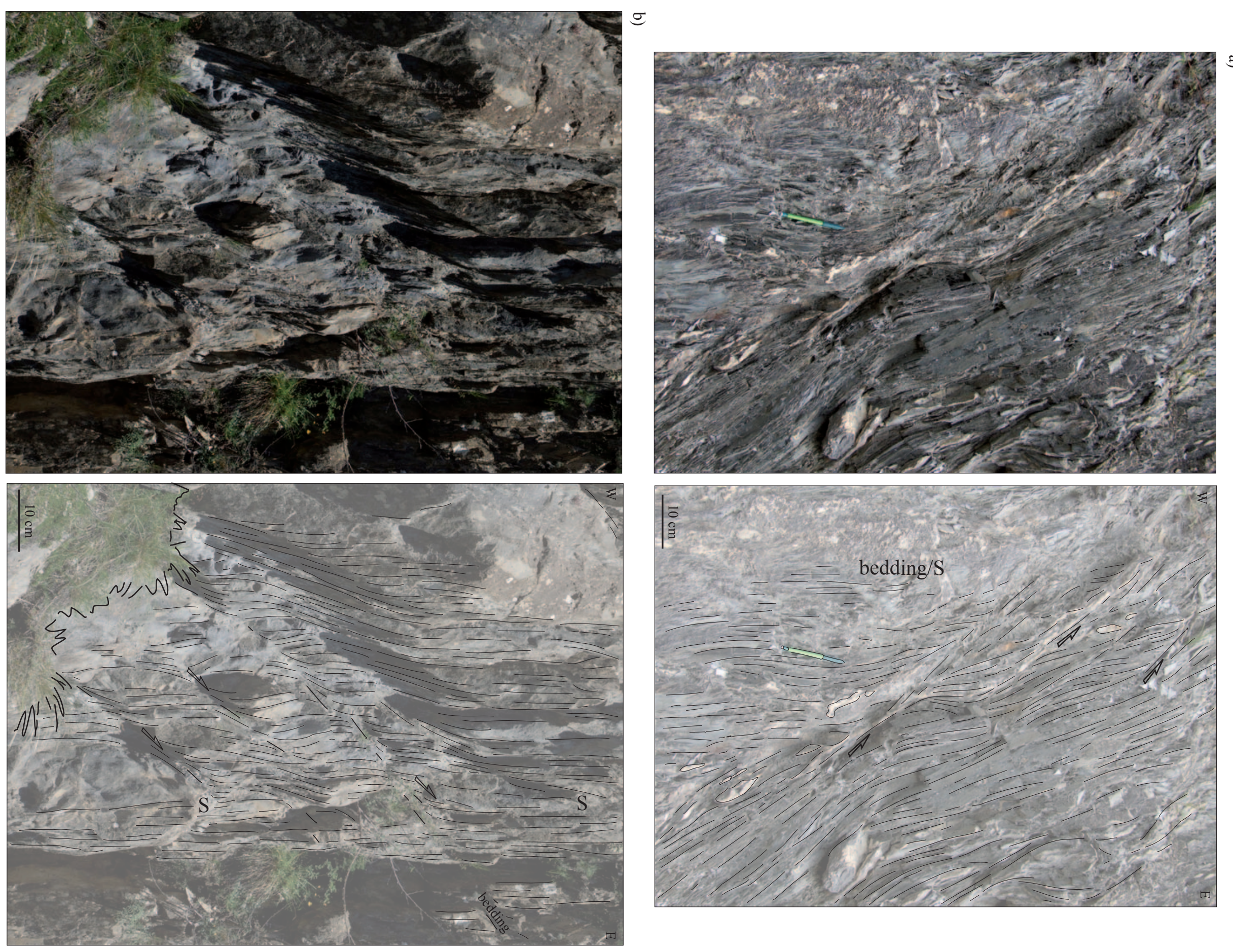
a)
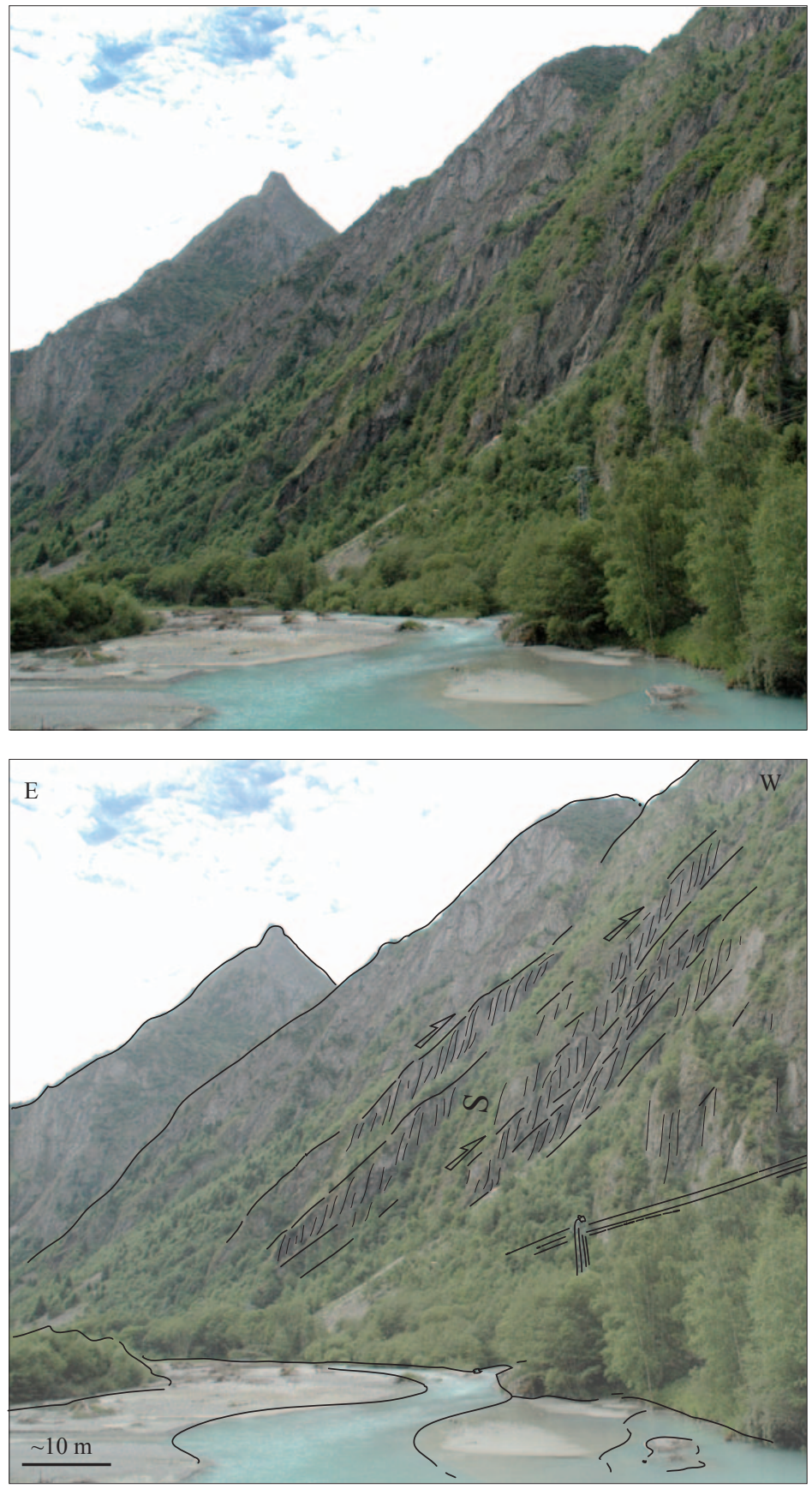

Figure 12 b)
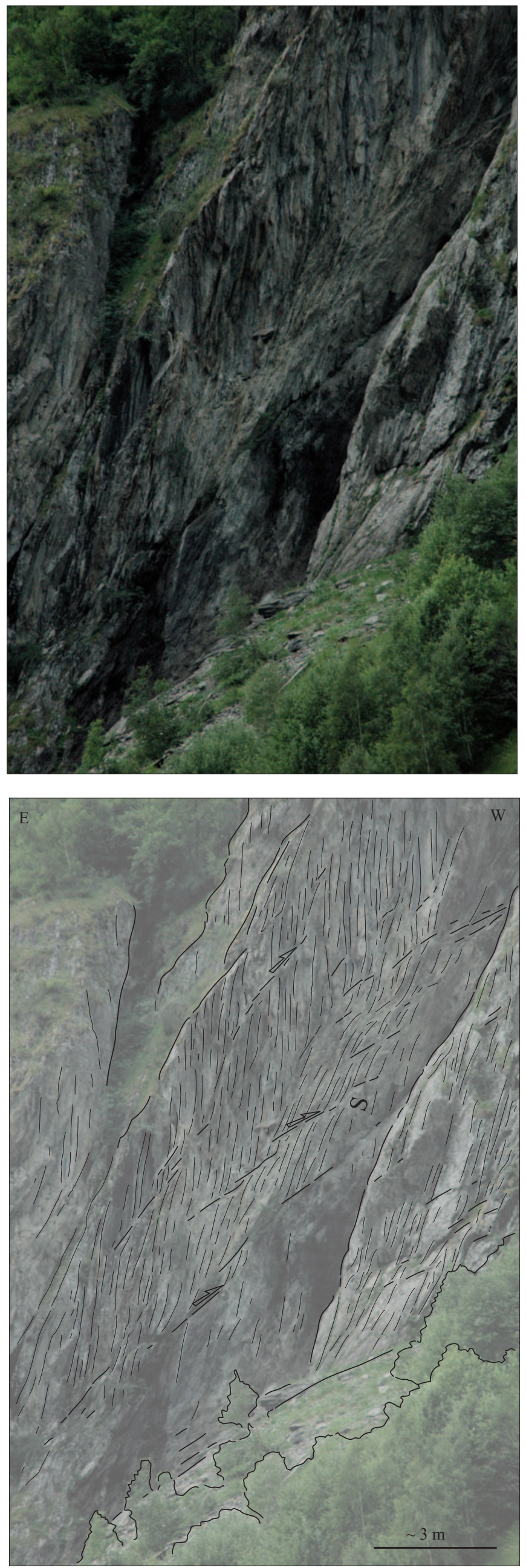
a)

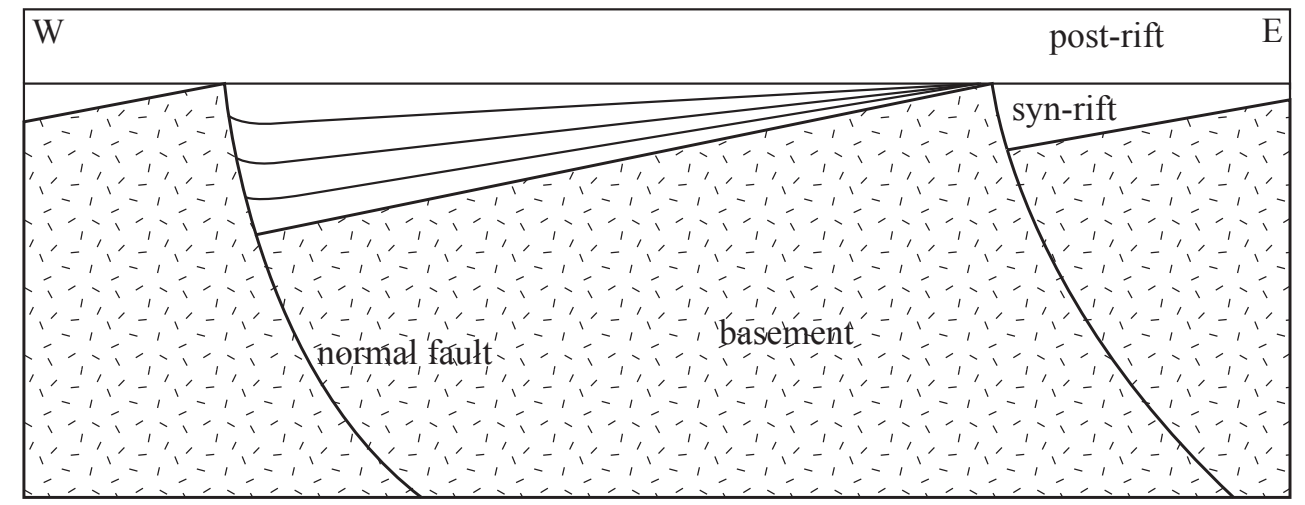

b)
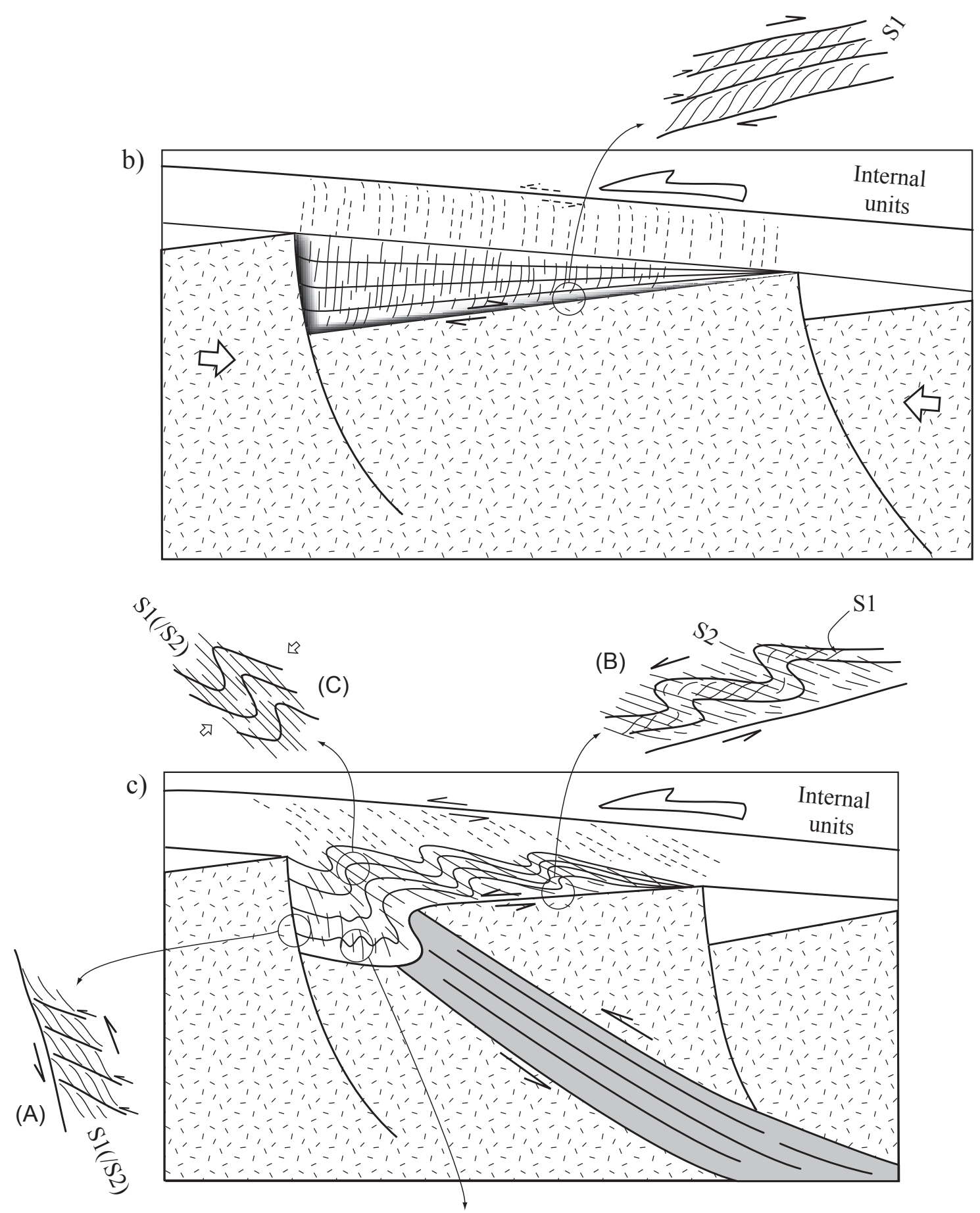

(D) $\Rightarrow$

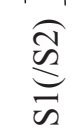

Figure 13 


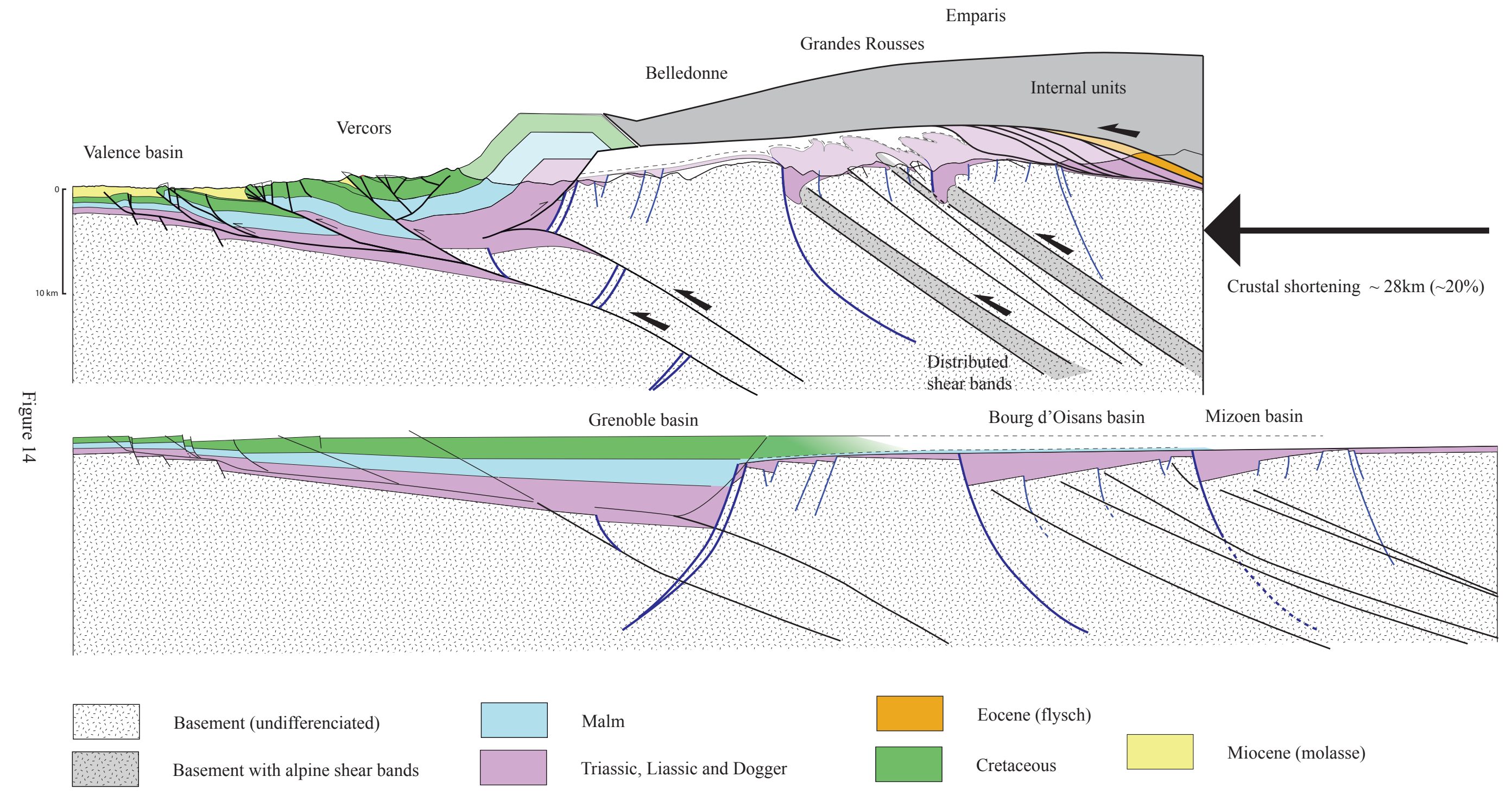


a) Initial crust (Mesozoic)

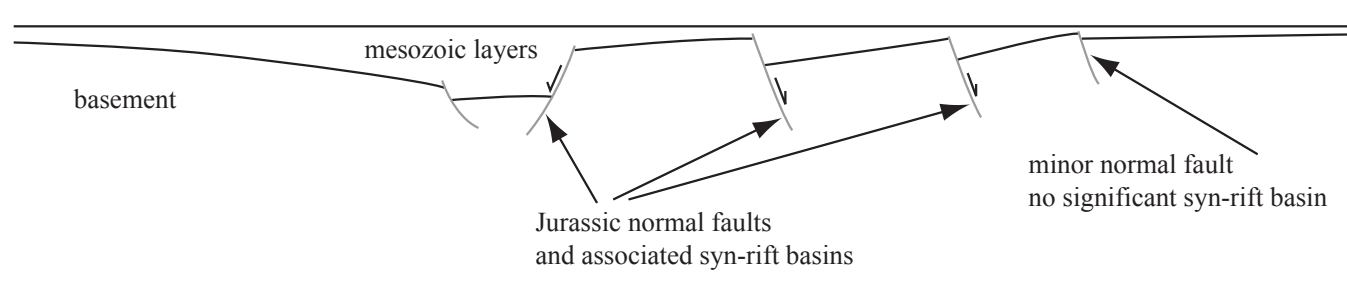

and associated syn-rift basins

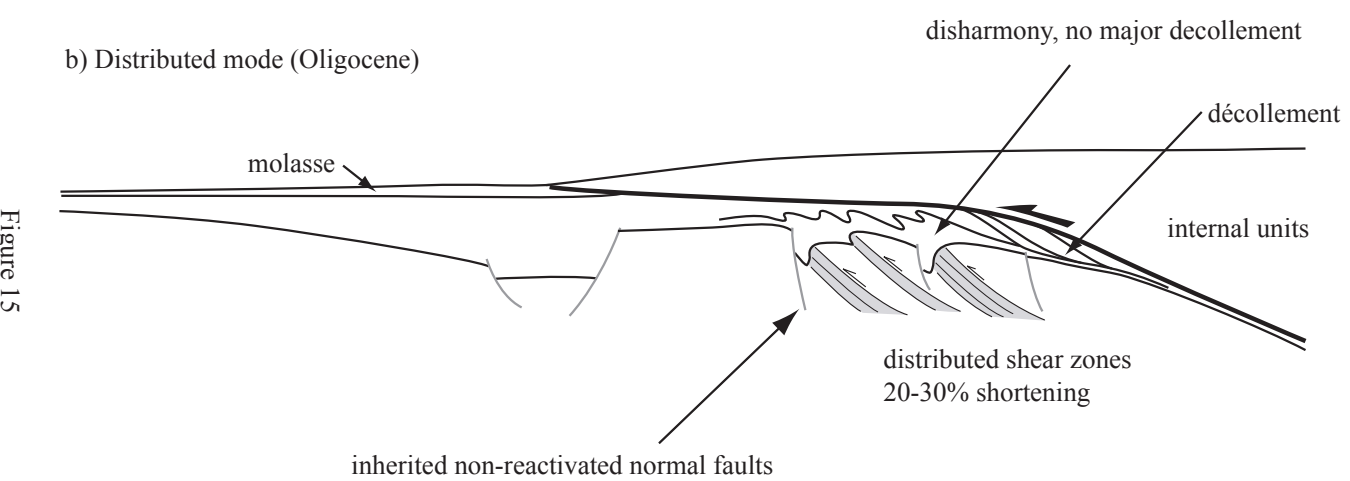

c) Localized mode (Miocene to present-day)

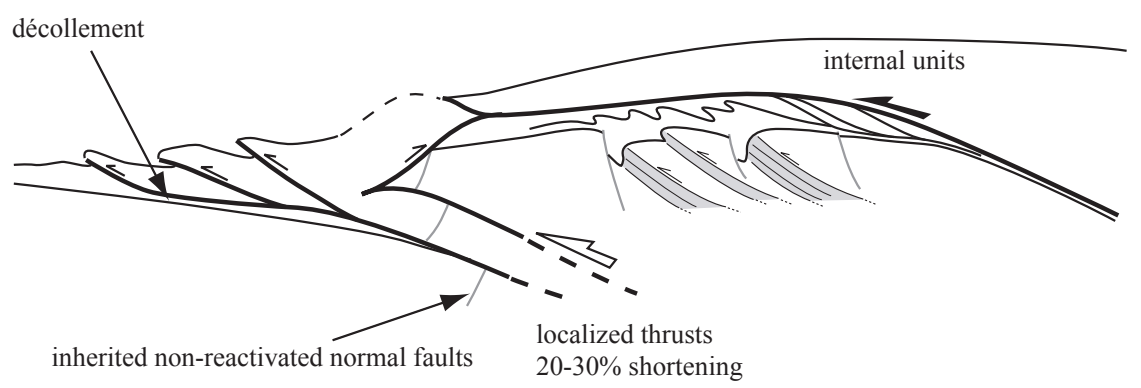

Crust with inherited basin and fault
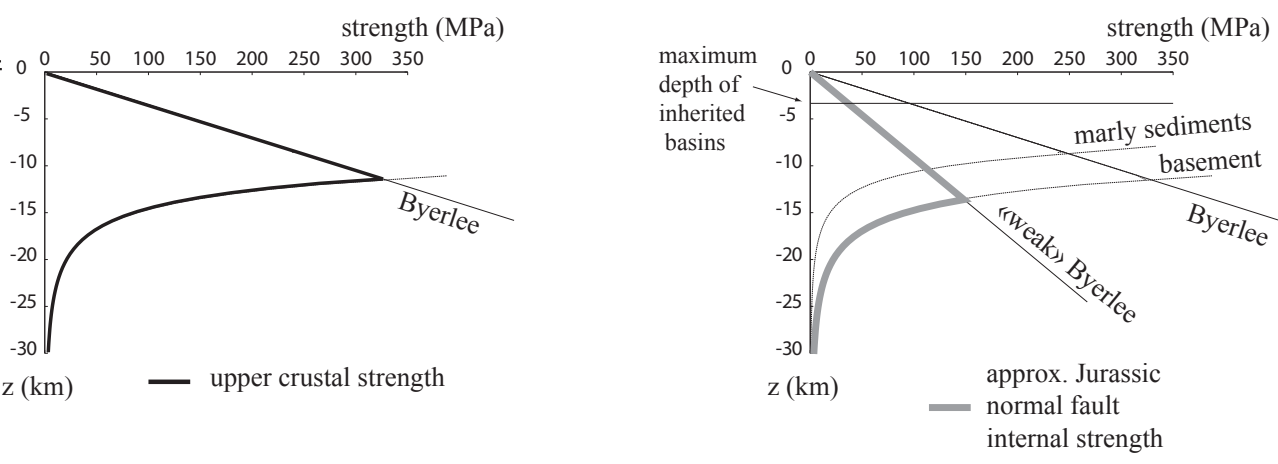

weakening effect

of the inherited basin

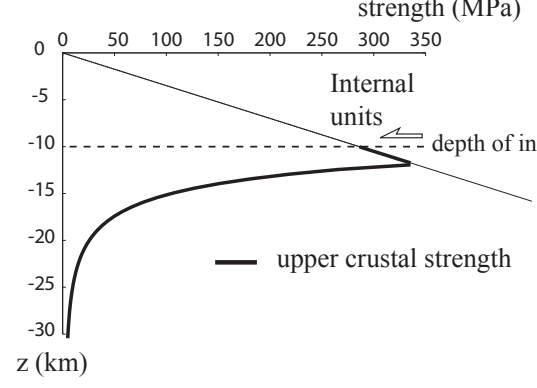




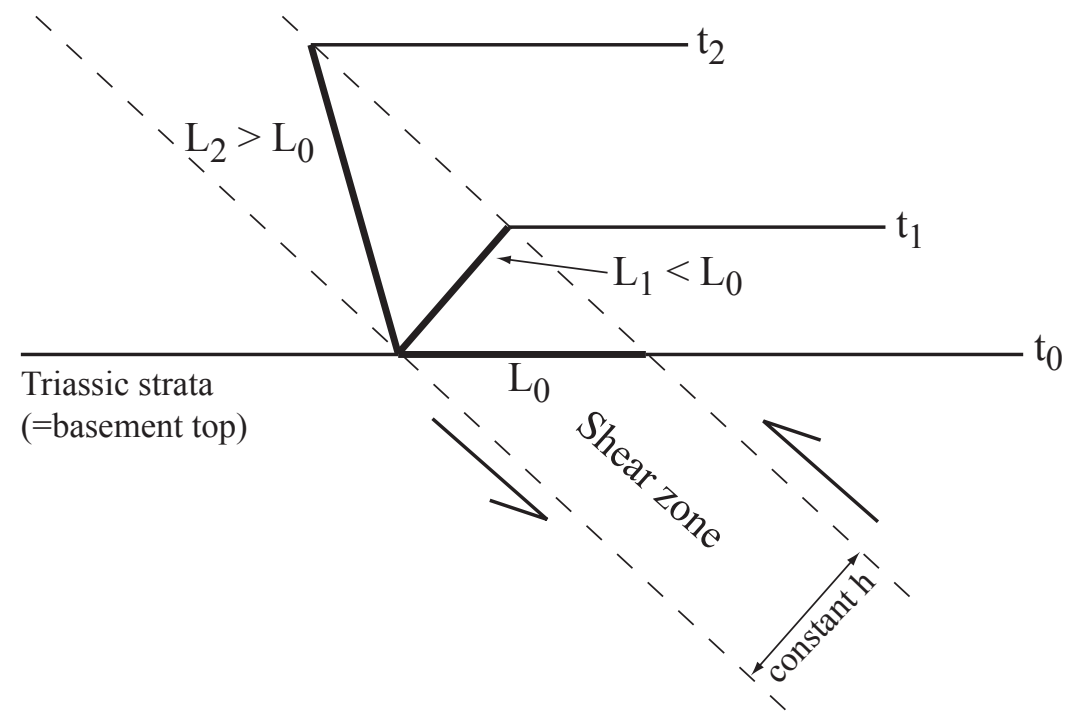

